\title{
Interpreting Rights: An Essay for Robert Cover
}

\author{
Martha Minow†
}

\begin{abstract}
I can't reconcile the sight of a battered child with the belief that we choose what happens to us, that we create our own world.
\end{abstract}

-Gloria Anzaldúa

Rights are under attack. Some conservatives criticize the expansion of rights for lacking a legitimate basis, for contributing to adversariness and social conflict, or for undermining respect for law. Some left-leaning scholars criticize rights because they are incoherent and indeterminate, or because they fail to promote community and responsibility. Whatever the reason, rights criticism abounds.

A rather obvious historical observation might explain the current popularity of rights criticism. Legal and political reforms in the last few decades have successfully established new rights based upon race, gender, environment, age, and handicap, and many legal scholars disapprove of these directions of change. On the other hand, the actual articulation and enforcement of these rights in specific contexts has disappointed those who seek more significant changes. Perhaps, more subtly, the visions of human relationships implied by newly recognized rights disturb and disappoint both those who have faith in traditional cultural forms and those who have hopes for as yet unrealized alternatives. Once rights are perceived as vulnerable to attack, they are widely perceived as inadequate.

One contemporary development in legal scholarship that offers a response to each of these critiques of rights describes law's method as "interpretation." As a theory of judicial action, this interpretive turn no doubt owes a debt to similar developments in theories of social science, literary

$\dagger$ Professor of Law, Harvard University. I am deeply grateful for the help given by Joe Singer, Jim Brudney, Richard Fallon, Willy Forbath, Mary Joe Frug, Mary Ann Glendon, Chris Desan Husson, Frank Michelman, Austin Sarat, Elizabeth Schneider, Avi Soifer, Vicky Spelman, Kathleen Sullivan, Cass Sunstein, and George Taylor; for the advice of the Yale Law Journal editors, especially

Nancy Marder, Tanina Rostain, and Andrea Stumpf; for the communities of inquiry created by two wonderful feminist reading groups, and for the privilege of hearing presentations by Mari Matsuda, Gerald Torres, Patricia Williams, Harlon Dalton, Robert Williams, and Denise Carty-Bennia at the

1987 Critical Legal Studies Conference on Racism as I revised this essay.

1. Anzaldúa, La Prieta, in This Bridge Called MY BaCk 198, 208 (C. Moraga \& G. Anzaldúa eds. 1981). 
criticism, philosophy, and theology. ${ }^{2}$ In law, scholars of many political stripes join in the interpretive turn. ${ }^{3}$ Perhaps the idiom of interpretation is capacious enough to permit replication of longstanding legal debates over the purposes and nature of law and judicial action. ${ }^{4}$ I defend here a particular version of the interpretive turn in law, the version depicting law as a communal language and attaching law to the social contexts in which norms can be generated and given meaning.

I also defend a version of interpretation that struggles with and against established patterns of power and authority. ${ }^{\circ}$ In my view, efforts to create

2. See, e.g., R. Bernstein, Beyond Objectivism and Relativism: Science, Hermeneutics, and Praxis (1983) (social theory); M. Buber, Between Man and Man (1959) (theology); T. Eagleton, Literary Theory (1983) (literary theory); S. Fish, Is There a Text IN This Class? (1980) (same); C. Geertz, The Local Knowledge (1983) (anthropology); T. KuhN, The Essential. Tension (1977) (philosophy of science); P. Ricoeuer, Interpretation Theory (1976) (philosophy); R. Rorty, Philosophy and THE MirRor of Nature (1979); P. Winch, The Idea of a Social Science and Its Relation to Philosophy (1958) (social theory); see also R. Bellah, R. Madsen, W. Sullivan, A. Swidler \& S. Tipton, Habits of the Heart: IndividUAlisM AND COMMITMENT IN AMERICAN LIFE (1985) (sociologists adopting interpretive approach); D. LACAPRA, HistoRY \& CRITICISM (1985) (discussing debate among historians about interpretation); R. Levins \& R. Lewontin, The Dialectical. BiologisT 273-88 (1985) (exploring ideologies of biological theories and proposing dialectical approach emphasizing relationships both among parts that compose whole and between observer and observed); Bell, The Turn to Interpretation: An Introduction, 51 PARTISAN REV. 215, 218 (1984) (introducing symposium on interpretive turn which "signifies the turn of the social sciences-or of those practitioners of this art-from the models of the natural sciences and their modes of inquiry, to the humanities"); Papke, Neo-Marxists, Nietzscheans, and New Critics: The Voices of the Contemporary Law and Literature Discourse, 1985 AM. B. Found. Res. J. 883 (reviewing J.B. White, When Words Lose Their Meaning (1984)).

3. See Brest, Interpretation and Interest, 34 Stan. L. REv. 765 (1982); Fish, Fish v. Fiss, 36 Stan. L. Rev. 1325 (1984); Fiss, Objectivity and Interpretation, 34 STan. L. Rev. 739 (1982); Interpretation Symposium, 58 S. CAL. L. Rev. 1 (1985); Symposium: Law and Literature, 60 TEX. L. REv. 373 (1982); Weisberg, A Response to Fish and White, 5 Miss. C.L. REv. 57 (1984); White, Law as Rhetoric, Rhetoric as Law: The Arts of Cultural and Communal Life, 52 U. CHI. L. REv. 684 (1985); see also McIntosh, Legal Hermeneutics: A Philosophical Critique, 35 OkLA. L. Rev. 1 (1982) (evaluating interpretive turn in legal theory); Patterson, Interpretation in Law-Toward a Reconstruction of the Current Debate, 29 ViLl. L. Rev. 671 (1984) (same); Phelps \& Pitts, Questioning the Text: The Significance of Phenomenological Hermeneutics for Legal Interpretation, 29 ST. LouIs U.L.J. 353 (1985) (same). Although some scholars emphasize the multiplicity of meanings in legal texts, the multiple notions of the interpretive enterprise, and the search for certainty as itself a symptom of our "collective disorder," Levinson, On Dworkin, Kennedy, and Ely: Decoding the Legal Past, 51 Partisan Rev. 248, 262 (1984), two newcomers to the enterprise, Charles Fried and Richard Posner, emphasize the fixity of meaning. See Fried, Sonnet LXV and the "Black Ink" of the Framers' Intention, 100 Harv. L. Rev. 751 (1987); Posner, Law and Literature, 72 VA. L. Rev. 1351 (1986).

4. See Minow, Law Turning Outward, TELOS (forthcoming) (comparing law and literature movement with critical legal studies and law and economics; law and literature movement seems to include participants across camps defined by other schools of thought).

5. Thus, this project addresses two distinct, and yet, overlapping debates within academic disciplines: (1) the methodological debate over interpretation versus positivism and functionalism; and (2) the aspirational debate over whether to use knowledge to struggle against dominant patterns of power or to treat knowledge as indifferent to, or cooperating with, established power arrangements. As currently played out, methodological interpretivists contest whether interpretation can be a form of critique and methodological positivists argue over whether empirical work (or, for lawyers, positive state sanctions) can or should challenge existing social arrangements. Another battle line is drawn between those who advocate resistance to established power through interpretive strategies, and those who seek to discover facts, rights, or authority for change. A chart summarizing these lines may help explain 
and give meaning to norms, through a language of rights, often and importantly occur outside formal legal institutions such as courts. "Legal interpretation," in this sense, is an activity engaged in by nonlawyers as well as by lawyers and judges. Interpretive activity appeals not to one overriding authoritative community, but instead to people living in worlds of differences. Through interpretive activity, people summon up a sense of potential community membership without relinquishing struggles over meaning and power.

This interpretive approach to law offers a promising defense against the two-fronted war on rights waged by right-wing and left-wing critics. It responds to the charges from the right that "new rights" lack objective foundations and to the charges from the left that rights are indeterminate by pointing to the social and intellectual processes by which individuals and groups make meaning. This approach responds to a charge from the right that rights promote conflict rather than community, and to a claim from the left that rights reinforce individualism at the expense of community. ${ }^{6}$ The interpretive approach permits debate over legal and political choices without pretending a social harmony that does not exist and without foreclosing social changes as yet unimagined. It grounds rights in the processes of communication and meaning-making, rather than in abstract or enduring foundations.

The first part of this essay defends the interpretive approach. I pursue these interpretive themes and develop what may seem to be a counterintuitive defense of rights as tools to express and strengthen community. The second part of the essay turns to an important challenge to the interpretive approach posed by Robert Cover's essay, Violence and the Word. ${ }^{7}$

why scholars often feel they have strange bedfellows and surprising opponents:

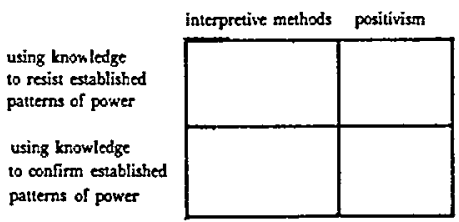

I believe that the interpretive method more fully accounts for other methods and therefore is superior to them, but I recognize that the very criteria for evaluating competing methods are incommensurate and inconsistent. Persuasion across camps, therefore, is unlikely to proceed in methodological terms.

6. Although there is an intriguing convergence here between the right and left invocations of "community," the term "community" no doubt signals divergent conceptions. See Parker, Issues of Community and Liberty, 8 Harv. J.L. \& PuB. POL'y 287 (1985) (distinguishing conservative republican community that includes hierarchy from populist republicanism, which is committed to equality). Compare Berns, Does the Constitution "Secure These Rights?," in How Democratic Is THE Constitution? 56, 76 (R. Goldwin \& W. Schambra eds. 1980) (authoritarian community) with M. Walzer, Spheres of Justice (1983) (liberal community) and Lynd, Communal Rights, 62 Tex. L. REv. 1417 (1984) (community of social change).

7. Cover, Violence and the Word, 95 YALE L.J. 1601 (1986) [hereinafter Violence and the Word]; see also Cover, The Bonds of Constitutional Interpretation: Of the Word, the Deed, and the 
Indeed, as in other areas, Cover's work changes the terms of discussion; we cannot go on the way we were going after we hear his words. The second half of this essay engages the terms of the debate Cover introduces, and takes seriously his call to unearth what the interpretive approach may conceal.

In an effort to avoid the usually abstract nature of discussions of debates over rights and legal interpretation, I will explore these themes in the context of children's rights. A heated debate about whether the rights of adults should extend to children occupies litigation and social commentary. Even rights declared in the past for children may be withdrawn, and the vulnerability of children's rights to shifting interpretations demonstrates the human authorship of rights. ${ }^{8}$ For me, the question is very truly how to "reconcile the sight of a battered child with the belief that we choose what happens to us, that we create our own world," through action and interpretation.

When I started work on this project not long ago, I thought to myself, Bob Cover will help me sort this out, and help me see where I am wrong. I knew he was working on the essay that became Violence and the Word; I knew he was critical of "interpretive" legal scholarship for suppressing the difference between law and the interpretation of literary texts. Yet, I also drew sustenance from from his conceptions of interpretive communities, and his own practice of creating them. I am one of so many people left, as Avi Soifer says, in mid-conversation, bereft of words to describe this loss of a man who so understood what words can and cannot say. This essay, for Bob, is my small effort to reach toward the kind of conversation he will inspire for years to come.

\section{A Critique of the Critiques}

Can we create meaning for our lives without demeaning the lives of others?

-Thomas Szasz ${ }^{10}$

Two widely announced criticisms of current legal developments are that

Role, 20 GA. L. REv. 815 (1986) [hereinafter The Bonds of Constitutional Interpretation].

8. See infra note 28 and accompanying text (discussing shifts in constitutional rulings about minors' rights in criminal justice system). Minors' First Amendment rights also may be undergoing renovation. Compare Tinker v. Des Moines Indep. Community School Dist., 393 U.S. 503 (1969) with Bethel School Dist. No. 403 v. Fraser, 106 S. Ct. 3159 (1986); see also Kuhlmeier v. Hazelwood School Dist., 795 F.2d 1369 (8th Cir. 1986), cert. granted, 55 U.S.L.W. 3493 (1986) (censorship of student newspaper rejected by circuit court; Supreme Court review pending).

9. Anzaldúa, supra note 1.

10. T. Szasz, The Manufacture of Madness 287 (1970). 
rights have proliferated without legitimate authority and that this explosion of rights has produced, as well as expressed, dysfunctional social conflict, litigiousness, and loss of community ${ }^{11}$ Both charges have been extensively debated, so I will not rehearse the arguments here. Suffice it to say that serious public figures and scholars challenge new kinds of legal rights for lacking basis in the text of the Constitution and other anchors of legal authority; ${ }^{12}$ some even charge that the preoccupation with rights is an illness in this society that prevents the development of social harmony. ${ }^{13}$

Scholars associated with the Conference on Critical Legal Studies advance another critique of rights. Some of these scholars argue that rights are internally incoherent because they articulate contradictory goals, such as "freedom" and "security." Such incoherence, according to the critics, permits the evils of manipulation and mystification by those who wield rights rhetoric, and produces alienation in those who confront the legal system. In addition, some scholars criticize prevailing rights for presupposing and reinforcing a notion that every individual is autonomous and

11. See L. Friedman, Total Justice 6-22 (1985) (discussing perceived "litigation explosion," crisis of legal legitimacy, and charges of "too many lawyers"). Friedman's analysis explores the substance of a "new legal culture" that includes a "general expectation of justice" and "a general expectation of recompense." Id. at 43. This analysis identifies modern doctrinal developments and invites judgment in these terms rather than in terms of the increasing number of lawyers and lawsuits. See also Galanter, Reading the Landscape of Disputes: What We Know and Don't Know (and Think We Know) About Our Allegedly Contentious and Litigious Socicty, 31 UCLA L. REv. 4 (1983) (arguing that perceptions of pathological litigiousness in U.S. are incorrect).

12. See, e.g., The Federalist Soc'y, The Great Debate: Interpreting Our Written ConSTITUTION (1986) (speeches by Attorney General Edwin Meese III, Justice William J. Brennan, Jr., Justice John Paul Stevens, Judge Robert H. Bork, and President Ronald Reagan); Berns, supra note 6; Brest, Meese, the Lawman, Calls for Anarchy, N.Y. Times, Nov. 2, 1986, at E23, col. 1. The search for foundations is often treated as a show-stopper in a cultural and political milieu uncertain about ultimates. Yet the dictionary defines "foundation" as simply the underlayer upon which we place subsequent layers-not an ultimate bedrock. See WEESTER's NEW Collegiate Dictionary 454 (1977) (foundation is "the act of founding," "the basis upon which something stands or is supported," and "a body or ground upon which something is built up or overlaid"). We create foundations; we found institutions; we are participants, constituting an order. The integrative, interactive frame of analysis adopted in this essay does not, however, respond to the objectivist or functionalist theorists in terms of their own criteria that express a contrasting theory of knowledge and meaning. See also Berns, supra note 6 (we can assess degree of "democracy" of Constitution by looking to issues involved in its ratification).

13. See, e.g., R. Morgan, Disabling America: The "Rights Industry" in OUR Time 3 (1984) (expanding concern over civil liberties in America has "disable[d] major American institutions, both governmental and private"); Bork, The Struggle over the Role of the Court, 34 NAr'L REv. 1137 (1982); Silberman, Will Lawyering Strangle Democratic Capitalism?, REG., Mar.-Apr. 1978, at 15, 44 (harmful effect of expanding legal process on society).

14. For an elegant version of this claim, see Dalton, An Essay in the Deconstruction of Contract Doctrine, 94 YALE L.J. 997 (1985) (discusses inconsistency and indeterminacy of contract doctrine). This charge can be met with the response that legal rules are applied in specific contexts, and by reference to specific contextual features we can resolve, at least for that instant case, the tension between, say, freedom and security. In context, similarly, language takes on meaning. Any word repeated many times out of context can come to sound absurd, but in context and use, people endow it with meaning. Contexts themselves are mutable, not given, yet by moving between word and context, and by choosing among contexts, people make meanings and test them with their ways of living. 
disconnected from others, instead of connected in important ways to other individuals and to society in general. ${ }^{18}$ This communitarian challenge resembles the yearning for social harmony present in the writings of some conservative critics, ${ }^{16}$ although conservative and radical scholars diverge on their particular conceptions of community, the good, and the concerns of individuals.

These debates about legal texts resemble debates in literary theory about the meaning of literary texts. ${ }^{17}$ Can the reader discern the "true" meaning of the text, the author's intent, or some other authoritative meaning? Or is each text always susceptible to multiple interpretations, with no authoritative meaning? ${ }^{\text {18 }}$ It is perhaps not surprising that legal theorists and literary theorists read and cite each other in the midst of their debates. ${ }^{19}$ Some legal theorists hope to find foundations for legal meaning in the analogy to literary interpretation, perhaps foundations in specific communities of interpreters; others hope to expose the multiple, and sometimes suppressed, meanings of legal texts.

Debates in legal and literary theory converge in the work of several authors who have developed ideas about the ways that texts help to create communities, to establish shared discourse, and to provide contexts for linking past with future, and creativity with tradition. James Boyd White, Milner Ball, Ronald Dworkin, and Robert Cover have each expressed variations on this set of ideas, which I call the "interpretive turn." White writes that "[l]egal argument is an organized and systematic process of conversation by which our words get and change their meaning."20 Ball

15. My own work has criticized rights for preserving an inquiry into "real difference" in the equal protection context, see Minow, When Difference Has Its Home: Group Homes for the Mentally Retarded, Equal Protection and Legal Treatment of Difference, 22 HARv. C.R.-C.L. L. REv. 111 (1987) [hereinafter Minow, When Difference Has Its Home], and for emphasizing autonomous individualism rather than communal responsibilities, see Minow, "Forming Underneath Everything That Grows": Toward a History of Family Law, 1985 WIS. L. REv. 819. In these works, I also have argued for reinterpreting rights to embody a richer conception of human interdependence. This essay is another effort to read rights in this way.

16. See R. Nisbet, The Question for Community (1953).

17. See Violence and the Word, supra note 7, at 1606 n.15. Christopher Norris, a literary theorist, in discussing the debates in literary theory and legal theory, has compared what he calls "conservative uses of the analogy between law and literature," which appeal to consensus meanings, with a deconstructive approach, which emphasizes the irreconcilable choices posed by texts. C. NoRRIS, THE Contest of FACULTIES 182 (1985); see id. 167-92.

18. See Fish, Working on the Chain Gang: Interpretation in Law and Literature, 60 TEx. L. REV. 551 (1982); Fish, supra note 3.

19. The Fish-Fiss debate is an obvious instance. See Fish, supra note 3; Fiss, supra note 3; Fiss, Conventionalism, 58 S. CAL. L. REv. 177 (1985); see also Levinson, supra note 3, at (legal theorists engaged in debate about nature of textual interpretation).

20. J.B. WhItE, supra note 2 , at 268 . Similarly, he argues: "This Constitution-like other such instruments-is thus in a literal sense a rhetorical Constitution: it constitutes a rhetorical community, working by rhetorical processes that it has established but can no longer control. It establishes a new conversation on a permanent basis." Id. at 246 . My concern about White's work is that it paints too cozy a picture of the world, assuming agreement and commonality precisely where they are lacking. 
explains: "I have proposed law as medium-law as connecting rather than disconnecting, enhancing a flow of dialogue, containing the dynamics of life in common."21 Dworkin suggests that

Law's attitude is constructive: it aims, in the interpretive spirit, to lay principle over practice to show the best route to a better future, keeping the right faith with the past. It is, finally, a fraternal attitude, an expression of how we are united in community though divided in project, interest, and conviction. ${ }^{22}$

Cover evokes the normative universe that "is held together by the force of interpretive commitments-some small and private, others immense and public." ${ }^{23} \mathrm{He}$ adds that "[t]he intelligibility of normative behavior inheres in the communal character of the narratives that provide the context of that behavior."24 For Cover, the kinds of communities in which normative meanings can be nurtured are likely to be outside official secular legal culture, and may even be undermined by the official legal rules. Nonetheless, his framework for understanding legal meaning-official and unofficial, public and private-depends upon a notion of meaning-making through communal narratives.

Before drawing on these interpretive themes, I should try to clarify what I mean by "rights," an overused word in legal, philosophical, and political debates. Defining "rights" is a difficult task because there is considerable ambiguity in the meanings invoked in the debates about rights, and because much ink has been spilled by legal and political theorists on this subject. One meaning is the formally announced legal rules that concern relationships among individuals, groups, and the official state. "Rights" typically are the articulation of such rules in a form that describes the enforceable claims of individuals or groups against the state. ${ }^{25}$

My own approach seeks to make disagreement and difference central when different people interpret their social relations through a rhetoric of rights.

21. M. Ball, Lying Down Together: Law, Metaphor, and Theology 122 (1985). He specifically suggests that we can "discern in international law the shaping of a forum and a language for the dynamics of international conversation." Id. at 66.

22. R. Dworkin, Law's Empire 413 (1986). Perhaps more than the others, Dworkin is interested in finding foundations for legal decisions, but he rejects the possibility of discerning the author's intent, see id. at 228-29, and instead, analogizing legal and literary interpretation, calls for exploration of the layers of meaning and tensions between practices and purposes. See id. at 47-49.

23. Cover, The Supreme Court, 1982 Term-Foreword: Nomos and Narrative, 97 HARv. L. REv. 47 (1983) [hereinafter Nomos and Narrative]. Cover's critique of the interpretive turn is the subject of Section II of this essay.

24. Id. at 10 .

25. Some theorists have offered typologies of rights and analyses of the relation among kinds of rights. See I. BERLIN, Two Concepts of Liberty, in FOUR EsSAYS ON LIBERTY (1969) (distinguishing positive and negative liberties); W. Hohfeld, Fundamental Legal ConCEPTIONs (1919) (analyzing distinctions and relations among privileges, powers, immunities, and rights); R. UNGER, 2 POLIrics (forthcoming) (distinguishing immunity rights, solidarity rights, market rights, and destabiliza- 
Yet a second meaning will become important in this essay. "Rights" can give rise to "rights consciousness" so that individuals and groups may imagine and act in light of rights that have not been formally recognized or enforced. Rights, in this sense, are neither limited to nor co-extensive with precisely those rules formally announced and enforced by public authorities. Instead, rights represent articulations-public or private, formal or informal-of claims that people use to persuade others (and themselves) about how they should be treated and about what they should be granted. I mean, then, to include within the ambit of rights discourse all efforts to claim new rights, to resist and alter official state action that fails to acknowledge such rights, and to construct communities apart from the state to nurture new conceptions of rights. Rights here encompass even those claims that lose, or have lost in the past, if they continue to represent claims that muster people's hopes and articulate their continuing efforts to persuade.

Consciousness, or cognizance, of rights, then, is not simply awareness of those rights that have been granted in the past, but also knowledge of the process by which hurts that once were whispered or unheard have become claims, and claims that once were unsuccessful, have persuaded others and transformed social life. The connections between past and future claims of rights are voiced through interpretations of inherited understandings of rights. Interpretation engages lawyers and nonlawyers in composing new meanings inside and outside of legal institutions. Charges against new rights express opposition to this interpretive process.

\section{A. The Charges Against Children's Rights}

Familiar criticisms of rights are quite pronounced in the context of children's rights. Perhaps no one denies a child's right to live, and therefore, to be safe from murder. ${ }^{26}$ Children's rights include many of the rights

tion rights); Golding, The Primacy of Welfare Rights, 1 Soc. PHIL. \& PoL'Y 119 (1984) (comparing right to liberty with welfare rights as entitlements to goods); Unger, The Critical Legal Studies Movement, 96 HARv. L. REv. 561, 597-600 (1983). Although some of these distinctions may be helpful to particular arguments developed in this essay, the general definition of rights offered in the text will be the touchstone for my analysis, and I do not mean to engage directly the vast philosophical literature on rights. See, e.g., R. Dworkin, Takinc Rights Seriously (rev. ed. 1977); A. Gewirth, Human Rights (1982); N. MacCormick, Legal Rights and Social Democracy (1982); A. Melden, Rights and Persons (1977); J. Rawls, A Theory of Justice (1971). See generally Theories of Rights (J. Waldron ed. 1984) (essays on varied conceptions of rights).

As signified by my second definition of rights, I mean to downplay the significance of the state both in the generation and enforcement of rights; instead, I am interested in the normative discourse of rights. See also Cover, Folktales of Justice: Tales of Jurisdiction, 14 CAP. U.L. REv. 179 (1985) [hereinafter Folktales of Justice] (exploring normative language apart from official power).

26. Early treatment of infanticide and contemporary debates about abortion suggest that even this "right to live" is less than obvious, and that certainly there remains debate about when life begins for this purpose. See K. Luker, Abortion and the Polrtics of Motherhood (1984) (reviewing abortion debates); L. Stone, The Famil.y, SeX and Marriage in England 1500-1800, at 296-99 
enjoyed by adults, such as rights to freedorn of expression, ${ }^{27}$ freedom from unwarranted searches and seizures, ${ }^{28}$ and freedom of choice about whether to terminate a pregnancy. ${ }^{28}$ Children's rights also could include rights particular to children, like a right to quality education tailored to meet the individual's needs, a right to decent foster care when under state custody, or a right to a hearing before suspension from public school. Children's rights may take the form of claims for independence and freedom from constraint, claims for care and protection, or claims for relationships with others. ${ }^{30}$

These days, children's rights have become a subject for jokes, as well as a target for critiques of judicial excesses. A cartoon in a newspaper may show a little tyke introducing a stranger to his parents: "Mom and Dad, I'd like you to meet my lawyer." J1 Jokes point out extremes and incongruities. We select these oddities for humorous jibes not simply at random, but because they make us uncomfortable. Children's rights make adults uncomfortable because they represent new ideas, or old ideas in new

(abr. ed. 1979) (discussing traditional acceptance of infanticide).

27. Tinker v. Des Moines Indep. Community School Dist., 393 U.S. 503 (1969). But see Ginsberg v. New York, 390 U.S. 629 (1968) (approving conviction for sale of magazines to minor although magazine would not be obscene if sold to adults).

28. In New Jersey v. T.L.O., 469 U.S. 325 (1985), the Court ruled that children do enjoy Fourth Amendment protections, but that their content may differ from the protections assured to adults. Compare In re Gault, 387 U.S. 1 (1967) (guaranteeing juvenile rights to hearing, cross examination, and counsel in juvenile court proceedings) with Schall v. Martin, 467 U.S. 253, 265 (1984) (denying minors protections against preventive detention because minors lack liberty interest identical to that of adults).

29. Planned Parenthood of Cent. Mo. v. Danforth, 428 U.S. 52 (1976). But see H.L. v. Matheson, 450 U.S. 398 (1981) (states may require parental notification before unemancipated minor dependent upon her parents may obtain abortion).

30. See H. Cohen, Equal Rights for Children (1980); M.D.A. Freeman, The Rights and Wrongs of Children (1983); L. Houlgate, The Child \& the State: A Normative TheORY OF Juvenile Rights (1980); Rodham, Children's Rights: A Legal Perspective, in ChilDRen's Rights: Contemporary Perspectives 21 (P. Vardin \& I. Brody eds. 1979); Whose Children?: Children's Rights, Parental Authority, and State Power (W. Aiken \& H. LaFollette eds. 1980). See generally Minow, Rights for the Next Generation: A Feminist Approach to Children's Rights, 9 HARv. Women's L.J. 1 (1986) [hereinafter Minow, Rights for the Next Generation] (exploring links between struggles for children's rights and women's rights); Minow, Are Rights Right for Children? 1987 AM. BAR. Found. RES. J. (forthcoming) (reviewing IN THE INTERest of Children (R. Mnookin ed. 1985)).

31. A best-selling humor book includes a rhyme that betrays a lingering sense of incongruity in the idea of "children's rights," or perhaps, an imagined triviality of the kinds of concerns represented by rights for children: "Strike! Strike! For Children's Rights /Longer week ends /Shorter school hours / Higher allowances /Less baths and showers / No brussel sprouts /More root beer /And seventeen summer vacations a year! If you're ready to strike-line up right here." S. SILvERSTEIN, A LIGHT IN THE. ATTIC 128-29 (1981). An article directed at nonlawyers cites as absurd the case of a Colorado student who sued his parents for intentional infliction of emotional distress after they punished him for smoking and selling marijuana. Mikva, Judges and Other People's Children, in Parenthood 220, 222-23 (R. Cohen, B. Cohler \& S. Weissman eds. 1984); see also An Interview with Marian Wright Edelman, 44 HARv. Educ. REv. 53, 66-67 (1974) (critical of "liberation" for children, who instead need "special protections"); Hafen, Children's Liberation and the New Egalitarianism: Some Reservations About Abandoning Youth to Their "Rights," 1976 B.Y.U. L. REv. 605 (critical of rights for children). 
forms, and signal that adults and existing practices have to change. Perhaps, though, jokes about children's rights express, through the art of trivializing, the positions of power adults generally have over children. Too often, the vulnerability of children is forgotten in a culture that assigns responsibility for their care, in the first instance, to the private sphere of particular parents. ${ }^{32}$ This pattern exonerates anyone but the child's parents from responsibility for the care and needs of the child and shields the child from public view. Current patterns of damage to children, due to poverty and other social conditions, should disturb our complacency about this public neglect. ${ }^{33}$ Advocates for children typically make claims about children's rights, despite prevailing rules of parental and judicial discretion, in an effort to challenge public complacency and to yield particular results in particular cases.

Increasingly, children's rights have triggered sharp ideological debates. Such conflict was raised by Goss v. Lopez, ${ }^{34}$ where the Supreme Court considered what process was due to children facing disciplinary action by school officials. The ideological debate in Goss involved competing views of human relationships. The plaintiffs demanded due process hearings before a student could be suspended from school. This demand invoked the autonomy and entitlement of each student: Each student deserves an opportunity to be heard before facing punishment; thus, each child needs a judicial grant of an individual right to restrain the actions of school authorities. In contrast, the defendants presented a conception of school as community, or family. In such a setting, the interests of individuals are shared. Continuing relationships would be frustrated by the formality and distance imposed by legal procedures-that is, by rights. In his dissenting opinion in Goss, which he read aloud from the bench, Justice Powell emphasized that

In assessing in constitutional terms the need to protect pupils from unfair minor discipline by school authorities, the Court ignores the commonality of interest of the State and pupils in the public school system . . . . In mandating due process procedures the Court misapprehends the reality of the normal teacher-pupil relationship. There is an ongoing relationship, one in which the teacher must occupy many roles-educator, adviser, friend, and, at times, parentsubstitute. It is rarely adversary in nature except with respect to the

32. See Minow, Rights for the Next Generation, supra note 30, at 5-8 (discussing patterns of cconomic and psychological risks for children and neglect of children in public arena).

33. See infra note 123 (discussing child abuse statistics).

34. 419 U.S. 565 (1975). Franklin Zimring and Raymond Solomon provide a thoughtful exploration of the facts and arguments behind the litigation in a recent case study that provides the basis for some of my analysis. See Zimring \& Solomon, Goss v. Lopez: The Principle of the Thing, in IN THE INTEREST OF CHILDREN 450; supra note 30. 
chronically disruptive or insubordinate pupil whom the teacher must be free to discipline without frustrating formalities. ${ }^{35}$

In the terms of this debate, the recognition of rights seems to define and accentuate the distance between people. Rights for students seem to pin them in adversarial relationships to teachers and school administrators.

The debate over the proper rules governing relationships are especially intense when children and public schooling are the focus. Choices about the next generation starkly require society to make decisions about fundamental values for the future. The rules that govern life within the school also convey a message to students about the world beyond the school. The significance of the choice of rules was not lost on the plaintiffs in the Goss litigation. Lawyers for the children sought to weave into their arguments the idea that "freedom and democracy are necessary in the schools to teach the young democracy." ${ }^{\text {"36 }}$ Justice Powell adopted an equally emphatic argument on the other side:

Education in any meaningful sense includes the inculcation of an understanding in each pupil of the necessity of rules and obedience thereto .... When an immature student merits censure for his conduct, he is rendered a disservice if appropriate sanctions are not applied or if procedures for their application are so formalized as to invite a challenge to the teacher's authority-an invitation which rebellious or even merely spirited teenagers are likely to accept. ${ }^{37}$

Implicit in Justice Powell's position are two objections to the assertion and grant of rights for children. The first is that rights, when claimed and recognized, create conflict and adversarial relations between children and adults where there otherwise would be community and shared interests. The second is that children lack the kind of autonomy and competence presumed by the idea of a right, and therefore, require protection from adults. Ghildren's rights would undermine this critical relationship be-

35. 419 U.S. at 593-94 (Powell, J., dissenting); see also Parham v. J.R., 442 U.S. 584 (1979) (presuming nonadversarial relationship between children and parents who seek to commit children to mental hospitals, and treating medical professionals as capable of providing independent review of parents' decisions).

36. Letter from Eric Van Loon to Denis Murphy and Ken Curtin, quoted in Zimring \& Solomon, supra note 34 , at 476 (letter accompanying draft brief).

37. 419 U.S. at 593 (Powell, J., dissenting) (footnote omitted). 
tween children and adults. ${ }^{38}$ But the interpretive approach to legal analysis provides another vantage point from which to view these objections. ${ }^{39}$

\section{B. Interpreting Conflict and Affirming Community}

Legal language translates, but does not initiate, conflict. ${ }^{40}$ The fear that judicial recognition of rights for children would inject conflict and invite

38. Although child-rearing notions are themselves deeply imbued with the political attitudes dominant in a particular culture at a given historical moment, many theorists have emphasized how the relationship between parent and child demands that parents have authority to restrict children's personal freedom. See, e.g., J. KAGAN, The NATURe of THE Child 257-64 (1984). Some theorists have maintained that the child must internalize a sense of parental authority, and that external intervention between parent and child will undermine the development of this sense of internalized limits. The child will grow up feeling weak, and will want to find others to be scapegoats. See C. LASCH, HaveN IN A HEARTLEss WORLD 174-78 (1977) ("delegation of discipline to other agencies" than family promotes projection of "forbidden impulses" onto outcast groups); Frenkel-Brunswick, Parents and Childhood as Seen Through the Interviews, in The Authoritarian Personality 358, 359 (T. Adorno, E. Frenkel-Brunswick, D. Levinson \& R. Sanford eds. 1950) ("[T]he existing identification with the parents is often accompanied by a more basic identification with mankind and society in general."). One legal observer suggests that "in a paradoxical but important sense, a child has a basic right to be protected against freedom" precisely because learning about the consequences of bad judgments is an important part of childhood. Hafen, Exploring Test Cases in Child Advocacy, 100 Harv. L. REv. 435, 446 (1986) (reviewing IN THE INTEREST OF ChILDREN (R. Mnookin ed. 1985)). Thus, Hafen, and others, have warned against "abandoning children to their rights." Id. at 445-46.

39. Although some observers criticize reliance on legal rights for introducing adversariness, or for emphasizing autonomy rather than cooperation, see J. HANDLER, THE CondrTIONS of DisCRETION: AUTONOMY, COMmUNITY, BuREAUCRACY 72-76, 121-58 (1986), others charge various forms of the interpretive turn with submerging conflict among groups, see Soifer, Reviewing Legal Fictions, 20 GA. L. REV. 871 (1986) (criticizing White). See generally Abel, Delegalization: A Critical Review of Its Ideology, Manifestations and Social Consequences, in ALTERNATIVE Rechtsformen UND ALTERNATIVEN ZUM RECHT: JAHRBUCH FÜR RECHTSSOZIOLOGIE UND RECHTSTHEORIE 27 (E. Blankenburg, E. Klausa \& H. Rottleuthner eds. 1980). I suggest that law is one arena, complete with language and institutions, where conflict can be enacted and temporarily resolved. The translation of conflict into legal discourse is not without consequences. Some of the consequences could include distorting the nature and scope of perceived conflict by the demand of an established idiom. Fitting women's claims, for example, into an equality framework that makes sameness to men a prerequisite may distort or deny the importance of differences. See, e.g., Finley, Transcending Equality Theory: $A$ Way Out of the Maternity and the Workplace Debate, 86 CoLUM. L. REv. 1118 (1986). See generally L. Peattie \& M. Rein, Women's Glaims: A Study in Political Economy 102-26 (1983) (exploring how prevailing system shaped claims of U.S. Women's movement, which, in turn, raised new categories of claims). Yet, the law itself can be reshaped by the conflicts brought to it. See, e.g., California Fed. Savings \& Loan Ass'n v. Guerra, 55 U.S.L.W. 4077 (U.S. Jan. 20, 1987) (No. 85494) (interpreting Title VII's antidiscrimination commitment to be consistent with California's pregnancy disability leave statute).

40. As with so many translations, something may be lost in the process. See G. STEINER, AFTER Babel: ASPECTS of LANGUAGE AND TRANSLATION (1975). Using language that is not one's own can limit, distort, and even silence. See Minow, Learning To Live with the Dilemma of Difference: Bilingual and Special Education, 48 LAw \& CONTEMP. Pross. 157, 165-56 (1985) (discussing effect of exclusively English-language schooling on children primarily fluent in another language); Finley, supra note 39, at 1163-65 (1986) (discussing limits of legal language to respond to women's issues); see also MacKinnon, Pornography, Civil Rights, and Speech, 20 HARv. C.R.-C.L. L. REv. 1, 14 (1985):

[I] you are the tree falling in the epistemological forest, your demise doesn't make a sound if no one is listening. Women did not 'report' [rape and battery] events, and overwhelmingly do not today, because no one is listening, because no one believes us. This silence does not mean nothing happened, and it does not mean consent.

The formality of processes set in motion by rights claims may also alter or even impede certain kinds 
rebelliousness is mistaken in two ways, as demonstrated by the Goss $v$. Lopez litigation. First, conflict was present long before anyone asserted in court that students had rights. Minority students were suspended without hearings after racial conflicts erupted in the Columbus, Ohio schools. ${ }^{11}$ The school administration had cancelled an assembly program organized by black students for Black History Week. Shortly thereafter, two black students were shot by white students. These events precipitated several disturbances. ${ }^{42}$ Following these events, a local chapter of the NAACP met with parents and students to discuss racism in the school disciplinary practices. $^{43}$

In such a context, it is difficult to believe that the introduction of legal rights would disrupt a community of nonadversarial interests shared among students and teachers. ${ }^{44}$ Similarly, where a pregnant minor seeks an abortion without parental consent because of her parents' religious or philosophical opposition, warm family consultation might be preferable, but may be impractical, given the circumstances. Denying the minor independent legal rights in such a situation hardly prevents conflict. ${ }^{45}$ Assertion of rights in these contexts does not initiate conflict, but rather gives it public expression and provides a method for public resolution. ${ }^{48}$

of communication. See, e.g., J. Mashaw, Bureaucratic Justice (1983) (discussing detriments and benefits of mass delivery of adversarial process in benefits context); Simon, Rights and Redistribution in the Welfare System, 38 STAN. L. REv. 1431, 1499-1504 (1986) (welfare jurisprudence distorted by rights rhetoric and analogy to private law). The claim of rights, however, need not predetermine the forms of requisite processes; people can use rights discourse to develop new procedures and remedies, as well as new claims. See J. HANDLER, supra note 39, at 141-53 (separating adversariness from liberal legalism and calling for cooperative dimension in reconstructing rights); MacKinnon, supra (advocating tort claims for women injured by pornography).

41. Zimring \& Solomon, supra note 34 , at $459-72$.

42. Id. at $460-61$.

43. Id. at $467-68$.

44. The Columbus, Ohio schools at the time of Goss were not unusual with respect to the presence of conflict. See generally S. Lightroot, Worlds APART: Relationships BeTweEn Families AND ScHools (1978) (exploring complex, and often conflicting, interactions among parents, teachers, children, and officials in school settings).

45.

It is difficult, however, to conclude that providing a parent with absolute power to overrule a determination, made by the physician and his minor patient, to terminate the patient's pregnancy will serve to strengthen the family unit. Neither is it likely that such veto power will enhance parental authority or control where the minor and the nonconsenting parent are so fundamentally in conflict and the very existence of the pregnancy already has fractured the family structure.

Planned Parenthood of Cent. Mo. v. Danforth, 428 U.S. 52, 75 (1976).

46. The use of rights rhetoric, and the warfare of litigation, can make covert conflict overt, and therefore, it may appear disruptive. See Fitzgerald, A Reporter at Large: A Disagreement in Baileyville, THE NEW YoRker, Jan. 16, 1984, at 47. Litigation per se may enlarge disputes that would otherwise smolder, but it also may narrow disputes that would otherwise expand. See Trubek, The Constitution and Deconstruction of a Disputes-Focused Approach: An Afterword, 15 LAw \& Soc'y REv. 727, 732-33 (1980-1981); see also Olsen, The Myth of State Intervention in the Family, 18 U. Mich. J.L. REF. 835 (1985) (exploring presence of state even when state does not "intervene"). Some might claim that the two problems suggested by Goss and Danforth represent extreme cases of conflict in settings usually characterized by harmony, and we would not devise rules for the extreme 
In other contexts, the charges that rights introduce conflict and adversariness have been levied by people who do not want to change existing patterns of domination. Such objections have been raised to criminalizing rape committed within a marriage ${ }^{47}$ and to giving employees rights. ${ }^{48}$ Rights, as both initial efforts to demand public debate about existing patterns of private power, and as official rules enforcing changes in those patterns, create conflict only by giving public voice and force to people previously ignored. Although such expression may amplify conflict and focus attention on it, it also may transform physical conflict into verbal disputes. ${ }^{49}$

Secondly, the introduction of rights to the school disciplinary process does not inject conflict because rights arguments, in essence, reconfirm community. The particular right ultimately announced in Goss amounted to no more than minimal notice and an opportunity for the student to have a conversation with a school official, much as any sensitive school official or parent would talk to a child before punishing her. ${ }^{50}$ This right

situation. Cf. Easterbrook, The Supreme Court 1983 Term-Foreword: The Court and the Economic System, 98 HARv. L. REv. 4, 10-14 (1984) (urging judicial attention to future consequences of principles laid down today rather than merely retrospective responses to particular fact situations). In response, I suggest that the rules we devise help create the exceptions, and the important challenge for the legal community is to build frameworks illuminated by what we may have made marginal in the past.

47. This view produced the traditional marital exception to rape laws, an exemption defended on the grounds that it promotes marital privacy and reconciliation. See Hilf, Marital Privacy and Spousal Rape, 16 NEw ENG. L. Rev. 31, 32-34 (1980); Comment, Rape and Battery Between Husband and Wife, 6 STAN. L. REv. 719 (1954). The current trend, however, expresses the contrary view that rape within marriage is blameworthy and is typically an expression of unequal power within the marriage and of actual spouse abuse. See Warren v. State, 255 Ga. 151, 336 S.E.2d 221 (1985) (disallowing marital exemption for rape); People v. Liberta, 64 N.Y.2d 152, 474 N.E.2d 567 (1984), cert. denied, 105 S. Ct. 2029 (1985) (holding marital exemption for rape unconstitutional); Note, To Have and To Hold: The Marital Rape Exemption and the Fourteenth Amendment, 99 HARv. L. REv. 1255 (1986) (urging analysis in terms of gender discrimination to expose power relations). For a discussion of the earlier view, barring "state intervention" from the family in the name of domestic harmony, see Note, Litigation Between Husband and Wife, 79 Harv. L. Rev. 1650 (1966).

48. See Weiler, Striking a New Balance: Freedom of Contract and the Prospects for Union Representation, 98 HARV. L. REv. 351, 357-63 (1984) (discussing institutional and conceptual obstacles to realizing employee rights).

49. But see C. MacKinnon, Sexual Harassment of Working Women 3-4 (1979) (discussing limits of legal language to express women's felt experiences). Legal language and structures may make some points of view less easily expressed or may even suppress them.

In the ritual legal opera only certain kinds of song can be performed; only certain persons can

sing. Less powerful characters may not be allowed on stage. This point goes to the formulation of ideas, their presentation in language and their legitimacy in law. . . . Law is a powerful mechanism for recognizing or hiding the desires and perspectives of those whose lives it governs.

O'Donovan, Family Law and Legal Theory, in Legal Thought and CoM̀mon LAw 184, 191 (W. Twining ed. 1986) (citation omitted).

50. 419 U.S. at 594-96 (Powell, J., dissenting). Some school officials suggest that Goss actually permits educational opportunities by framing discussions of discipline and fairness. Others suggest that Goss procedures inside the schoolhouse promote settlement of issues that might otherwise go to court. School Superintendents' Seminar, Harvard Graduate School of Education (June 17, 1986). 
to a conversation is a good example of the way in which asserting rights may actually affirm, rather than disturb, community. By invoking rights, an individual or group claims the attention of the larger community and its authorities. At the same time, this claim acknowledges the claimant's membership in the larger group, her participation in its traditions, and her observation of its forms. ${ }^{51}$ Although the language of rights, on its surface, speaks little of community or convention, those who exercise rights signal and strengthen their relation to a community. Those who are claiming rights implicitly agree to abide by the community's response, and to accord similar regard to the claims of others. ${ }^{62}$ In a deeper sense, those claiming rights implicitly invest themselves in a larger community, even in the act of seeking to change it. ${ }^{5 s}$ Stating a claim in a form devised by those

51.

The law establishes roles and relations and voices, positions from which and audiences to which one may speak, and it gives us as speakers the materials and methods of a discourse. . . . It is this discourse, working in the social context of its own creation, this language in the fullest sense of the term, that is the law. It makes us members of a common world.

J.B. Whrte, supra note 2, at 266; see also M. BALL, supra note 21, at 122 ("I have proposed law as medium-law as connecting rather than disconnecting, enhancing a flow of dialogue, containing the dynamics of life in common."); R. DwORKIN, supra note 22, at 63 (citing Wittgenstein for notion that participants in social practice must share form of life to recognize sense and purpose in what another says and does); Pitkin, Justice on Relating Private and Public, 9 Pol. Theory 327, 347 (1981)

(citing J. Tussman, Obligation and the Body Politic 78-81, 108, 116-17 (1960)):

Drawn into public life by personal need, fear, ambition or interest, we are there forced to acknowledge the power of others and appeal to their standards. . . . We are forced to find or create a common language of purposes or aspirations, not merely to clothe our private outlook in public disguise, but to become aware of its public meaning. We are forced, as Joseph Tussman has put it, to transform "I want" into "I am entitled to," a claim that becomes negotiable by public standards.

52. Barbara Harrison put this essentially Kantian insight this way: "If any of us is prepared to invoke anything as a human moral right on our own behalf, that very act implies the existence of a similar claim for every other member of our species." B. HARRISON, MAKING THE ConNECTIONS: EsSays IN Feminist Social. Ethics 168 (1985); see also Michelman, The Supreme Court 1985 Term-Foreword: Traces of Self-Government, 100 HARv. L. REv. 4, 43 (1986) [hereinafter Traces of Self-Government] ("It is the legal character that marks the output of the debate [of the commonwealth] both as the product of reason and as the expression of the citizens' concrete universality, their reciprocal recognition of sameness-within-difference."); Michelman, Justification (and Justifiability) of Law in a Contradictory World, 28 NOMOS 71, 92 (1986) ("a right, however much it may be a claim to respect as a distinct person, is, equally fundamentally, a claim grounded in human association"). This commitment to basic equality is the powerful appeal of rights rhetoric, even though the response to any claim ought to be understood as temporary. Any judgment, then, may set a precedent for the next case, but then again, it may not.

53. Martin Luther King's justification for "direct action" as a way to assert the rights of blacks intertwined notions of communal connection with demands for change:

Just as Socrates felt that it was necessary to create a tension in the mind so that individuals could rise from the bondage of myths and half-truths to the unfettered realm of creative analysis and objective appraisal, so must we see the need for nonviolent gadflies to create the kind of tension in society that will help men rise from the dark depths of prejudice and racism to the majestic heights of understanding and brotherhood. The purpose of our direct-action program is to create a situation so crisis-packed that it will inevitably open the door to negotiation. . . . Too long has our beloved Southland been bogged down in a tragic effort to live in monologue rather than dialogue.

King, Letter from a Birmingham Jail (Apr. 1963), reprinted in J. Williams, Eyes ON THE PRIzE: AMERICA's Civil Rights YeARS, 1954-1965, at 187 (1987). Such civil disobedience efforts express a 
who are powerful in the community expresses a willingness to take part in the community, as well as a tactical decision to play by the rules of the only game recognized by those in charge. ${ }^{\mathrm{s}}$

The skeletal due process mandated by Goss exposes how dependent individual rights are upon the established community order and how those rights forge connections among individuals by requiring people to respond to each other. ${ }^{b 5}$ Can the student persuade the vice-principal not to suspend her? Maybe not. For the student, "having the right" to try depends upon the willingness of the vice-principal to take that right seriously. Similarly, the Goss ruling announcing that right depended upon the willingness of the Justices to engage in a serious conversation about students' needs and, indeed, a willingness to include students as members of the community, bound together through rights. ${ }^{58}$

The due process right in Goss is special in its specific call for communication and attention to the individual student's dignity. Thus, both in its initial assertion and in its ultimate form, the right to a hearing before suspension from school engages student and school administrators in a process of discussion that can build a community of respect. Even beyond the particular right granted by the Supreme Court in Goss, the claim of any right initiates a form of communal dialogue. A claimant asserts a right and thereby secures the attention of the community through the pro-

commitment to the aspirations of a community belief inherent in "efforts." King continued, in his letter to the eight Alabama clergymen who urged the Negro community to press for rights in court but not in the streets: "I submit that an individual who breaks a law that conscience tells him is unjust, and willingly accepts the penalty by staying in jail to arouse the conscience of the community over its injustice, is in reality expressing the very highest respect for law." Id.

My notion of interpretation includes civil disobedience, and moreover, includes the activities of those who adopt the "community" interpretive framework as part of a tactical effort to be heard, and as a signal of a shared heritage and shared life.

Communities are those networks of people who believe their past communications had meaning and who have faith that future communications will also have meaning. Community members do not necessarily share substantive beliefs. Good friends who disagree strongly about ideologies, scientific propositions, and questions of taste remain good friends as long as they continue to use the same communicative framework.

L. Carter, Contemporary Constitutional Lawmaking: The Supreme Court and the Art OF Polrtics 15 (1985).

54. Such a claim represents an especially powerful statement when it is made by those who know they have been excluded in the design of the very procedures for self-governance. Thus, subgroups living within an essentially or even partly alien culture face a difficult dilemma in deciding whether to submit their disputes to the courts of the larger community. $C f$. J. Auerbach, Justice Without LAw? 69-94 (1983) (discussing resistance within immigrant communities to submitting disputes to governmental courts and retention of local religious or ethnic tribunals).

55. The results of some rights claims may be a ruling that some people do not have to deal with others. Successful privacy claims and restraining orders in domestic abuse cases, in particular, have this effect. Yet even these rulings result from an institutionally-framed discussion forcing people to recognize each other's boundaries.

56. See O'Neill, The Public Use of Reason, 14 PoL. ThEORY 523, 527, 548 (1986) (toleration as necessary for "plurality of potentially reasoning beings"); Tribe, Structural Due Process, 10 HaRv. C.R.-C.L. L. REV. 269, 305-06 (1975) (commitment to real dialogue at heart of legitimacy includes agreement to avoid privileged place of some views over others). 
cedures the community has designated for hearing such claims. ${ }^{87}$ The legal authority responds, and though this response is temporary and of limited scope, it provides the occasion for the next claim. Legal rights, then, should be understood as the language of a continuing process rather than the fixed rules. Rights discourse reaches temporary resting points from which new claims can be made.

Rights in this sense are not "trumps," but the language we use to try to persuade others to let us win this round. ${ }^{58}$ When advocates for children ask a court to recognize children's rights to privacy, due process, or other protections, they seek judicial statements that will articulate new boundaries and connections between children and adults. ${ }^{59}$ They seek the chance to use these judicial articulations to negotiate new relationships between children and adults in the arrangements of daily life. ${ }^{60} \mathrm{Here}$, rights provide a language which depends upon and expresses human interconnec-

\footnotetext{
57.

You could understand that a person arguing with you is giving you her time in a joint effort at mutual understanding. That way, argument is a form of cooperation. Argument might be thought of theatrically, along the lines of a dance, for example. The participants would then be taking part in a joint enterprise whose purpose is a performance that works. . . . The action becomes dialogue rather than diapolemics. And the outcome is something other than victory for one party and defeat for the other. The success of a play or a piece of music can be measured, it has been suggested, "by its ability to elicit connectedness."
}

M. BALL, supra note 21, at 133 (quoting The Talk of the Town, THE NEw YoRKER, Mar. 15, 1982 , at 33).

58. But see Dworkin, Rights as Trumps, in Theories of RIGHTs, supra note 25, at 153. Although particular rights by their very content may assert a power to "trump," both their origins and future viability depend upon a continuing, communal process of communication. No rights are selfenforcing. Enforcement remains contingent upon the willingness of the community's officials to signal their meaning to the community through force or threatened force. See infra Section II (responding to discussion of violence and power). Whether rights are "determinate," whether their stated content determines their specific meaning in particular contexts aside from the enforcement choices made by specific officials, has been a subject of considerable dispute. Compare Kelman, Trashing, 36 STan. L. REv. 293 (1984) (suggesting indeterminacy of rights and legal doctrinal categories) with Boyle, The Politics of Reason: Critical Legal Theory and Local Social Thought, 133 U. PA. L. REv. 685 (1985) (urging resolution of debates by reference to local, situated analysis) and Fiss, Objectivity and Interpretation, 34 STAN. L. REv. 739 (1982) (taking issue with indeterminacy thesis). I believe it is possible to avoid this dispute by conceiving of rights as part of legal language, used to express claims that depend upon particular choices, in specific contexts, for their meanings. See supra note 14. Those meanings are created not only by the discretionary judgments of the officials involved, but also by the conceptions of the litigants and the pressures produced by the broader polity. This is what I call the "interpretive approach."

59. In this sense, rights are like commitments, made binding by those who make them. "[R]ights are to law what conscious commitments are to the psyche." Williams, Alchemical Notes: Reconstructing Ideals from Deconstructed Rights, 22 HaRv. C.R.-C.L. L. REv. 401, 424 (1987).

60. This notion of a continuing process of setting and resetting boundaries through communal debate over rights claims resembles the conception of continual redefinition of the selfs boundaries, a conception powerfully present in the work of some psychologists. See, e.g., R. KEGaN, The EvolvING SELF (1982); Benjamin, The Oedipal Riddle: Authority, Autonomy, and the New Narcissism, in Authority in AMERICA 195 (J. Diggins \& M. Kann eds. 1981); Benjamin, The Bonds of Love: Rational Violence and Erotic Domination, in The Future of Difference 41, 47-51 (H. Eisenstein \& A. Jardine eds. 1980) (citing G. Hegel, Phenomenology of SpIRIt 111-19 (A. Miller trans. 1977)) (on master/slave relation). 
tion at the very moment when individuals ask others to recognize their separate interests. Giving children rights to testify in court about suspected child abuse-and even rights to testify on videotape, away from the defendant-tips the balance of power toward children, temporarily, without knocking them off the see-saw with adults.

In adopting this interpretive approach to rights, I mean to acknowledge both the attractive and unattractive baggage of rights discourse. The historical association of rights discourse in our culture with notions of equality, freedom, and respect for individuals is appealing. However, I mean to challenge and reject a different historical association of rights discourse: its tinge of legal positivism or objectivity that implies an authoritative basis or foundation beyond current human choices. Insofar as a given set of rights embodies the results of past struggles, it expresses a particular substantive commitment. The civil rights movement, for example, created a legacy of meanings for the Fourteenth Amendment, reflecting the commitment of the civil rights activists and the officials persuaded by them to incorporate elements of the movement into the formal legal system. Invocation of those commitments, and that history, can add to the persuasive force generated in rights discourse even when that discourse depends on nothing beyond current and future human choices.

Thus, claims of rights have a special resonance in our culture, but they are still vulnerable to rebuff. The rhetoric of rights draws those who use it inside the community, and urges the community to pay attention to the individual claimants, but underscores the power of the established order to respond or withhold response to the individuals' claims. In addition, the rhetoric of rights remains available for yet another individual or group to claim attention and participate, which may complicate or even jeopardize the claims already made by inviting a different community response.

This form of discourse draws each claimant into the community and grants each a basic, if minimal, equality to participate in the process of communal debate. James Boyd White put it this way: "[T]he [legal] case establishes an essential equality between people . . . and it proceeds by a method of argument and conversation that both recognizes the individual's view of his own situation and complicates that view by forcing him to recognize the claims of another." ${ }^{\text {"11 }}$ The discourse of rights registers commitment to a basic equality among the participants as participants, even when the participants are children. It is important, however, to distinguish the ways in which this basic form of equality creates a kind of community from the ways that inequality of power and status may well re-

61. J.B. WhITE, supra note 2, at 274. For a discussion of how the conversation among judges in multi-judge courts can, and should, provide a model for the self-governing conversation for the larger community, see Traces of Self-Government, supra note 52, at 34-36, 72-77. 
main within the community, and children provide important examples on both counts.

Relatively recently, children have become subjects, rather than objects, in the community bound together by rights discourse, and their participation registers a procedural equality: an equal right to be heard. The gradual emergence of the idea that children can, in fact, have rights marks a departure from an older view that adults have rights to children, as if children were property. ${ }^{62}$ In Smith $v$. Organization of Foster Families for Equality and Reform, ${ }^{\mathbf{6 3}}$ which challenged state decisions to remove foster children from their foster placements, the foster parents' attorney framed a complaint drawing on this old view. The complaint sought to establish that foster parents' rights over the child in their care would be sufficient to trigger a due process hearing before the state could move the child to another placement. ${ }^{64}$ The plaintiffs' attorney claimed to represent both the foster parents and foster children in their shared interest in maintaining relationships.

The district court, however, held that a potential conflict of interest between the children and the foster parents required separate representation of the children. Further, the district court treated the children as separate persons with distinct interests that must be voiced in the legal conversation. On this basis, the court appointed a separate attorney to speak for the foster children. ${ }^{85}$ Although the case ultimately yielded no answer to the constitutional question of due process rights in the foster care context, the fact that the district court, and the Supreme Court on review, considered the claims of the children's attorney suggests that the judiciary recognized children as distinct persons, deserving independent consideration. ${ }^{66}$ Moreover, Justice Stewart, joined by Chief Justice Burger and Justice Rehnquist, wrote separately to emphasize that the state law rejected the

62. For a fascinating account of the transformation of children's social value from economic producers to objects of affection, see V. Zelizer, Pricing the Priceless Child: The Changing Social Value of Children (1985).

63. 431 U.S. 816 (1977).

64. See Chambers \& Wald, Smith v. OFFER, in IN THE INTEREsT of ChILDREN, supra note 30 , at 81 .

65. The appointed counsel happened to be a lawyer with long-standing associations with several private foster care agencies essentially allied with the state in opposing due process rights for foster parents. Id. at 91-95. Even though the children's attorney opposed due process rights, she urged the court that no adult has a "right" to a child, and that foster parents cannot obtain "squatters' rights" to a child simply by caring for other people's children. Id. at 96-97.

66. The Supreme Court has not always recognized the distinct personhood of children. See Schall v. Martin, 467 U.S. 253 (1984) (Court authorized preventive detention for juveniles who, unlike adults, lack liberty); Parham v. J.R., 442 U.S. 584, 602 (1979) (presuming that parents act in their children's best interests, Court rejected claims that children deserve adversarial due process protections before civil commitment pursued by their parents). 
idea that long-term custody of children creates some sort of "'squatters' rights," "'67 as though children were property.

Here, the very claim of rights by the foster parents implicated the children in a communal process, which gave them roles as participants and entitled them to the basic equality of consideration accorded by legal institutions to community members. This basic equality should not be confused, however, with full political, social, economic, or cultural equality. Rights claims neither confer equality nor transform the community into one of complete equals, even though interpretivists, like White, sometimes talk as though communal discourse produces communities of equals. We know our communities are not like that. The assertion of membership accomplishes something important, but it does not itself disturb or challenge unequal arrangements of economic and political power. It is, of course, no news to either the powerful or the powerless that those with power have power. ${ }^{68}$

Children, in particular, are usually less powerful that others economically and politically, and certainly different, and more vulnerable, physically, emotionally, and mentally. The very content of rights children claim invoke protection against others, given such inequalities. Rights may entail different treatment, not the same treatment, precisely in recognition of differences between individuals and groups. ${ }^{68}$

What, then, is the equality signaled by rights discourse? The equality registered by rights claims is an equality of attention. The rights tradition in this country sustains the call that makes those in power at least listen. Rights-as words and as forms-structure attention even for the claimant who is much less powerful than the authorities, and for individuals and groups treated throughout the community as less than equal. ${ }^{70}$ The inter-

67. 431 U.S. at 857 (quoting Bennett v. Jeffreys, 40 N.Y.2d 543, 552 n.2, 356 N.E.2d 277, 285 n.2 (1976) (opinion of Stewart, J., concurring in judgment).

68. As Carol Gilligan has noted: "If you have power, you can opt not to listen. And you do so with impunity." Marcus, Spiegelman, DuBois, Dunlap, Gilligan, MacKinnon \& Menkel-Meadow, The 1984 James McCormick Mitchell Lecture: Feminist Discourse, Moral Values, and the Law-A Conversation, 34 Buffalo L. Rev. 11, 62 (1985).

69. A persistent problem with rights rhetoric, traditionally, is its implication of some essential "sameness" as both a precondition and consequence for basic equality. Another problem is the seeming "yes or no" quality of rights, rather than more fluid and flexible notions. See supra note 39. Both features of traditional rights discourse are not immutable, however, and rights can be urged precisely to recognize difference, see Krieger \& Cooney, The Miller-Wohl Controversy: Equal Treatment, Positive Action and the Meaning of Women's Equality, 13 Golden Gate U.L. Rev. 513, 564 (1983) (urging feminist litigators to adopt "a new model for sexual equality . . . one which can effectuate equality in the context of inherent sex differences"); Traces of Self-Government, supra note 52, at 43 (law should recognize citizens' "sameness-within-difference"), and to pursue shifting and flexible relief, see Chayes, The Role of the Judge in Public Law Litigation, 89 HARv. L. REv. 1281, 1300-01 (1976) (need for "ongoing remedial regime" in public law litigation where assumptions of community are challenged).

70. There remain unstated assumptions here, as in so many claims of equality: for example, equal to whom? Unstated is the presumed standard for comparison of the adult, white, competent male 
pretive approach construes a claim of right, made before a judge, as a plea for recognition of membership in a community shared by applicant and judge, much as reader and author share the world of the text. ${ }^{71}$ The language of rights voices an individual's desire to be recognized in tones that demand recognition. ${ }^{72}$ Rights discourse implicates those who use it in a form of life, a pattern of social and political commitment. ${ }^{73}$

Which claims will persuade, and how? With what consequences for prior and subsequent claims? Which claims, indeed, will be recognized as even deserving communal attention?74 These are difficult and persistent questions in a community committed to rights discourse. There is a risk that those points of view that have been silenced in the past will continue to go unheard, and will be least adaptable to the vocabulary of preexisting claims. These are issues for struggle, and some struggles may well take place beyond rights discourse, beyond language. Some people may feel so shut out that the appeal to a communal commitment to rights makes no sense to them. Nonetheless, an interpretive conception of rights is a way to take the aspirational language of the society seriously ${ }^{75}$ and to promote change by reliance on inherited traditions. It is a way to challenge those who want to close the doors now that some of the previously excluded have fought and found their way in. ${ }^{78}$

citizen. Efforts to disclose the unstated standard are especially important where there is a coincidence of knowledge and power: where the respected point of view goes unstated because the speaker is able to remain unaware of other points of view simply because the structures of privilege and power give his point of view the appearance of truth. See Minow, When Difference Has Its Home, supra note 15, at 179 (discussing feminist attempts to show that "knowledge and identity are forged in social relationships").

71. But will the judge shatter their shared world by directing, commanding, and legitimating a violent end? This is the question posed in Section II, infra.

72. This does not mean that there are no important differences between rights discourse and other kinds of conversations. See infra text accompanying note 190 (discussion of coerced conversations by litigants before court).

73. Cf. L. Wittgenstein, Philosophical. Investigations 46c-92c (G. Anscombe 3d ed. 1958) (exploring relation between language games and forms of life).

74. These questions may be included in what Cover considered as problems of jurisdiction, see infra text accompanying notes 201-02.

75. Young people, in particular, may take the aspirational rhetoric of adults seriously, even in moments of apparent political rebellion. See K. KentsTon, Young RAdicsls: Notes ON CommrTTED YouTH 127 (1968) (young radicals' nahive hope that political system would work produced frustration when it failed); K. Keniston, Youth and Dissent: The Rise of A New Opposition 214 (1971):

With these particular young men and women, studied in 1967, what was most impressive was not their rebellion against their parents or American society, but their ultimate fidelity to both-their principled acceptance of the core values of their families, which in almost every case were humanitarian, intellectual, liberal, democratic, and very American. Compared to these traditional values, our actual society seemed to these young radicals (as it does to me) grossly wanting.

76. Audre Lorde eloquently raised the problem that The Master's Tools Will Never Dismantle the Master's House, in SISTER OuTSIDER 110 (1984). She wrote: "What does it mean when the tools of a racist patriarchy are used to examine the fruits of that same patriarchy? It means that only the most narrow perimeters of change are possible and allowable." Id. at 110-11. Surely, legal discourse 
The metaphors of interpretation and conversation enable a conception of community connections forged through the exchange of words in the struggle for meaning. ${ }^{77}$ In a powerful novel about contemporary South Africa, Nadine Gordimer's Rosa Burger responds to a critic of liberalism by saying:

I'm not offering a theory. I'm talking about people who need to have rights-there-in a statute book, so that they can move about in their own country, decide what work they'll do and what their children will learn at school. . . . People must be able to create institutions-institutions must evolve that will make it possible in practice. That utopia, it's inside . . . without it, how can you . . . act? ${ }^{78}$

The use of rights discourse affirms community, but it affirms a particular kind of community: a community dedicated to invigorating words with power to restrain, so that even the powerless can appeal to those words. It is a community that acknowledges and admits historic uses of power to exclude, deny, and silence-and commits itself to enabling suppressed points of view to be heard, to make covert conflict overt. ${ }^{79}$ Committed to making available a rhetoric of rights where it has not been heard before, this community uses rights rhetoric to make conflict audible and unavoidable, even if limited to words, or to certain forms of words. ${ }^{80}$ If there is

is a paradigmatic case. Yet, just as Audre Lorde's own prose transformed inherited language and ideas, and claimed difference as "that raw and powerful connection from which our personal power is forged," id. at 112, an emphatic claiming of differences through rights language could help transform existing legal and social structures. To continue the metaphor of the Master's House, the tools may be used for renovations that make the house unrecognizable to its former landlords and more hospitable to others.

77. See supra note 20 (quoting White). But White's version is more comfortable, and perhaps more sanitized, than mine. In my view, if the conversations do not take place among equals, who have equal opportunities to contribute to and influence what is said and what it means, the conversations can reinforce, rather than correct, the patterns of domination. When the "conversation" is situated within legal institutions, and its consequences carry legal, and potentially physical, force, the patterns of domination become impressed with state power.

78. N. GoRdimer, BURGer's DAughter 296 (1979). The contrast between South Africa and the United States is telling. A South African visitor, watching the televised special "Eyes on the Prize" that chronicled the American Civil Rights Movement of the 1950s, told me that he was most amazed by the way that Martin Luther King and others invoked the symbols of the United States as banners for their struggles. That the Constitution and the Supreme Court represented ideals that could be claimed by the excluded seemed unthinkable to this South African. See also Dugard, The Jurisprudential Foundation of the Apartheid Legal Order, 18 PHIL. F. 115, 122 (1986-1987) (Black majority lost confidence in South African law given its role in apartheid); Goldberg, Reading the Signs: The Force of Language, 18 PHIL. F. 71, 89-90 (1986-1987) (language of racial difference reinforces historical race relations; "language can act as a brake upon the rate of social transformation").

79. See K. Ferguson, The Feminist Case Against Bureaucracy 22-29 (1984) (discussing subjugated discourses and possibilities for speaking about values and points of view excluded by contemporary bureaucracies).

80. For eloquent explorations of the processes of translation and distortion when people bring their claims to the legal system-and for depictions of resulting successes and failures, see R. HARRIS, 
conflict experienced in the introduction of rights rhetoric to a new area, it is over this issue: Should the normative commitment to restrain power with communal dedication reach this new area? The power in question may be public or private. For example, with children's rights, large disagreements persist over whether and how communal limits should constrain the exercise of private, especially parental, power. ${ }^{81}$ Children's rights may enlarge state power over both children and adults, not simply recognize children's pre-existing autonomy. ${ }^{82}$ But it is the meaning of autonomy, and its relation to rights, that claims attention next.

\section{G. Rights Do Not Presuppose Autonomy}

A persistent argument against rights for children is that children lack the autonomy necessary to engage in adversarial exchange, to protect their own interests, and, indeed, to know their own interests. ${ }^{83}$ This challenge to children's rights emphasizes the source of rights in traditional criteria, with objective foundations. Another challenge to children's rights stresses indeterminacy, and the seeming limitlessness of children's needs. ${ }^{84}$ These objections grow out of a more widely accepted conception of rights, which relies on the idea that the rights-bearing person is an autonomous individual capable of exercising choice for personal ends and able to protect personal freedom from the pressure and power of others. ${ }^{85}$ Yet a community

Freedom Spent (1976); R. Kluger, Simple Justice (1976); J. Noonan, Persons and Masks OF THE LAW (1976).

81. Since Goss v. Lopez, 419 U.S. 565 (1975), the Supreme Court has tended to conclude that public schools exercise official, rather than parental, power, and therefore, should be subject to legal restrictions. See New Jersey v. T.L.O., 105 S. Ct. 733, 741 (1985) ("If school authorities are state actors for purposes of the constitutional guarantees of freedom of expression and due process, it is difficult to understand why they should be deemed to be exercising parental rather than public authority when conducting searches of their students."); Ingraham v. Wright, 430 U.S. 651, 662 (1977) ("Although the early cases viewed the authority of the teacher as deriving from the parents, the concept of parental delegation has been replaced by the view-more consonant with compulsory education laws-that the State itself may impose corporal punishment as is reasonably necessary "for the proper education of the child and for the maintenance of group discipline.' ") (footnote omitted).

82. Michael Grossberg's study of nineteenth century family law suggests that the expanding protections for children and women essentially produced greater judicial power and discretionary control over families. M. Grossberg, Governing tHe HeARTH: LAW aNd tHe Family in NineteEnTHCentury America 287-307 (1985).

83. See, e.g., Hafen, supra note 31, at 644-56; Mnookin, The Enigma of Children's Interests, in IN THE INTEREST OF CHILDREN, supra note 30, at 16. But see Worsford, A Philosophical Justification for Children's Rights, 44 HARV. EDUC. REv. 142 (1974).

84. See Burt, Pennhurst: $A$ Parable, in IN THE INTEREst of ChILDREN, supra note 30 , at 324 (describing how all potential parties are moved by needs of mentally retarded people until "insatiability" of needs leads people to worry about costs and to worry about being overwhelmed).

85. See, e.g., Dworkin, Paternalism: Some Second Thoughts, in Paternalism 105 (R. Sartorius ed. 1983); Raz, Right-Based Moralities, in THEORIES OF RIGHTS, supra note 25, at 186-95. For alternative notions of rights, see Lynd, Communal Rights, 62 TEx. L. Rev. 1417 (1984) (exploring rights that build community); Schneider, The Dialectic of Rights and Politics: Perspectives from the Women's Movement, 61 N.Y.U. L. REv. 589 (1986) (exploring dialectic between experience and women's rights); Simon, Rights and Redistribution in the Welfare System, 38 Stan. L. Rev. 1433 
is presupposed by this notion of the autonomous rights-bearing individual-a community willing to recognize and enforce individual rights. Even this usual conception of rights, premised on autonomy, relies on a social and communal construction of boundaries among people. Boundaries, whether social, psychological, or legal, do not exist naturally; they are invented and reinvented by people in formal and informal ways. ${ }^{86}$ As a psychological matter, the very experience of a bounded personal identity requires not just one individual, but many who help constitute the boundaries. $^{87}$ In the words of one theorist, autonomy is a process of "parts that mutually specify themselves," like M.C. Escher's drawing of two hands, drawing each other. ${ }^{88}$

These insights about the precondition of relationships for the development of autonomy undergird current work in psychology, anthropology, and philosophy. Recent theories of human development emphasize how aspects of the self develop from experiences with others, notably the mother, such that " $[t]$ he core of the self, or self-feeling, is also constructed relationally." the child, but most importantly, to begin the process of individuation, the child needs to see the mother seeing him. ${ }^{90}$ Even beyond theories of child

(1986); see also T. Doi, The Anatomy of Dependence (J. Bester trans. 1973) (exploring Japanese conception of human interdependence in contrast to Western emphasis on autonomy). See generally Minow, When Difference Has Its Home, supra note 15 (describing traditional assumption of competence for rights-bearers and offering alternative approach emphasizing social relations).

86. See M. BALL, supra note 21, at 15 ("For us to live in a world in which even the boundaries are of our making is not so bad. If we had a foundation or objective boundaries, they might even get oppressively in our way."). See generally A. Cohen, The Symbolic Construction of CommuNITY (1985) (exploring social construction of membership and exclusion as elements of community); K. Erikson, Wayward Puritans: A Study in the Sociology of Deviance (1966) (exploring how Puritans assigned people to deviant positions as way of conceiving boundaries of their cultural universe).

87. See N. Chodorow, The Reproduction of Mothering 57-73, 99-110, 191-205 (1978) (psychological development of individual depends on relationship with parent through which individual boundaries are established).

88. Varela, The Creative Circle, in The Invented Reality 309-11 (P. Watzlawick ed. 1984).

89. Chodorow, Toward a Relational Individualism: The Mediation of Self Through Psychoanalysis, in ReCONSTRuCTING INDIVIDUALISM: AUTONOMY, INDIVIDUALITY, AND THE SELF IN WESTERN Thought 197, 201 (T. Heller, M. Sosna \& D. Wellbery eds. 1986); see also D. Dinnerstein, The MERMAID AND THE MiNotaUR (1976) (mother-child relationship affects child's development of boundaries). Chodorow relies in part on the work of object-relations theorists like Joan Riviere, who wrote:

There is no such thing as a single human being, pure and simple, unmixed with other human beings. Each personality is a world in himself, a company of many. . . . These other persons are in fact therefore parts of ourselves, not indeed the whole of them but such parts or aspects of them as we had our relation with, and as have thus become parts of us. And we ourselves similarly have and have had effects and influences, intended or not, on all others who have an emotional relation to us, have loved or hated us. We are members one of another.

Chodorow, supra, at 202-03 (quoting Riviere, The Unconscious Phantasy of an Inner World Reflected in Examples from Literature, in New DiRecrions in Psychoanalysis 358-59 (M. Klein, P. Heimann \& R. Money-Kyrle eds. 1955) (footnote omitted)).

90. D. WinnicotT, The Family and Individual Development (1965); Mahler, Symbiosis and Individuation: The Psychological Birth of the Human Infant, in 2 M. MAHLER, THE SE- 
development, psychologists have begun to identify the capacity to form commitments and connections to others, rather than autonomy, as the destination for the maturing person. ${ }^{81}$ Philosophers have developed similar insights. Drucilla Cornell interprets Hegel's view as suggesting that "[o]ne becomes a self-identified ego only through interaction in which one experiences oneself as a self by being mirrored in the eyes of others." ${ }^{92}$ The metaphor of conversation, used by interpretive legal theorists, adopts a similar view of the interdependence of individuals and the aspiration of connection..$^{83}$

According to this view, legal rights are interdependent and mutually defining. They arise in the context of relationships among people who are themselves interdependent and mutually defining. ${ }^{94}$ In this sense, every right and every freedom is no more than a claim limited by the possible claims of others. ${ }^{95}$ Rights, in fact, could be understood as simply the articulation of legal consequences for particular patterns of human and institutional relationships. ${ }^{98}$ Rather than expressions of some intrinsic autonomy, property rights announce complex, and often overlapping, relationships of individuals and the larger community to limited resources. ${ }^{97}$ Contract rights specifically govern the formation and dissolution

LECTEd PAPERS 149 (1979); Winnicott, The Theory of the Patent-Infant Relationship, in ThE MATurational Processes and the Facilitating Environment 37 (1965); Mahler, Thoughts About Development and Individuation, 18 Psychoanalytic Study Child 307 (1963).

91. See, e.g., C. Gilligan, In a Different Vorce 151-74 (1982).

92. Cornell, Toward a Modern/Postmodern Reconstruction of Ethics, 133 U. PA. L. REv. 291, 361 (1985) (discussing Hegel's Jena manuscripts); see also M. SANDEL, Liberalism AND THE LiMITS OF JUSTICE (1982) (criticizing protection of "unencumbered self" as goal of social arrangements).

93. Autonomy, even as an aspiration, is the invention of a cultural and linguistic community. Through words and concepts, we symbolically construct our relations to one another in ways that acknowledge our interdependence. See M. BALL, supra note 21, at 138 ("Freedom is the opposite of chaos. . . We are freed for that binding to others which locates and holds us no matter the dissolution of ordering boundaries or an order of oppressing boundaries."); C. GEERTz, supra note 2, at 73-93. White describes his approach to reading texts as analogous to change through interaction:

The idea of reading at work in this book is not simply the old-fashioned one of the discovery of meaning, nor is it the new-fashioned one of the creation of meaning by a community of readers; instead, it is the idea of an interaction between mind and text that works like an interaction between people-it is in fact a species of that-and the expectations we bring to a text should be similar to those we bring to people we know in our lives.

J.B. WhrTe, supra note 2, at 18.

94. Inequality in the process of mutual definition is a significant problem. Our definitions of ourselves are not equally regarded by others; majority groups have greater control over the definitions not only of themselves, but also over those they define as "other." See Minow, When Difference Has Its Home, supra note 15, at 169-73 (discussing labeling theory). Yet, the language of rights offers some hope: It is the language of protest made legitimate by the powerful, even for use by the powerless.

95. Hohfeld provides an elaborate articulation of the relational contexts in which rights assertions arise. See Singer, The Legal Rights Debate in Analytical Jurisprudence from Bentham to Hohfeld, 1982 Wis. L. REv. 975, 986-94.

96. See Minow, Many Silent Worlds, 9 W. New Eng. L. Rev. 197 (1987); Singer, The Reliance Interest in Property (Jan. 1987) (unpublished manuscript).

97. Singer, supra note 96; see also M. Glendon, The New Family and the New Property (1981) (exploring "new property" concepts cross-culturally). 
of commercial relationships. ${ }^{98}$ Constitutional rights, such as freedom of association, freedom of religion, and the fundamental rights to marry, procreate, and protect family ties, expressly describe legal claims to relationships. ${ }^{99}$ Perhaps less obvious, but no less powerful, are legal rights regarding tort liability, which give legal significance to relationships among strangers. ${ }^{100}$ The rights of a tort victim cannot be defined without reference to others affected by the damage claims. Most notably involved is the tortfeasor, but also implicated are those to whom costs may be shifted, through insurance or pricing mechanisms. ${ }^{101}$

Autonomy, then, is not a precondition for any individual's exercise of rights. The only precondition is that the community is willing to allow the individual to make claims and to participate in the shifting of boundaries. ${ }^{102}$ When a court acts, it defines the boundaries among people by

98. See I. MacNeil, The New Social Contract (1980) (urging recognition of long-term relationships rather than single transactions as theory for contract law); Macaulay, Non-Contractual Relations in Business: A Preliminary Study, 28 AM. Soc. REv. 55 (1963) (contractual planning and contracts used for renegotiations of long-term relationships); Wiseman, The Limits of Vision: Karl Llewellyn and the Uniform Commercial Code, 100 HARv. L. REv. 465, 504-09 (1987) (discussing Llewellyn's notion of merchant transactions in which relationships within community of repeatplayers should influence nature of rules). See generally Gottlieb, Relationism: Legal Theory for a Relational Society, 50 U. CHI. L. REv. 567 (1983) (advocating "relationism" perspective about judicial arrangements between institutions, groups, and others bound in ongoing long-term relations); Green, Relational Interests, 30 ILL. L. REv. 314 (1935) (exploring significance of political, group, familial, professional, and commercial relations for law).

99. See Weisbrod, Family, Church and State, Legal History Program Working Paper \#2, Institute for Legal Studies, University of Wisconsin, Madison Law School. But see Minow, The Invention of Tradition: The Constitution and the Family 73 J. AM. Hist. (forthcoming) (constitutional doctrines about families convert conflicts among religious and ethnic groups into conflicts between state and family).

100. See G. Galabresi, The Costs of Accidents (1970); Minow, supra note 96. Placing human relationships on a spectrum moving from high to low degrees of intimacy, legal rules have prescribed the terms and consequences of family and trustee/beneficiary relations, relations bound and set by contractual terms, and relations among strangers. Transformations in the legal rules governing each of these groups have been striking. Although legal rules once presumed an identity of interests among family members and precluded access to law for resolving intra-family disputes, current developments articulate the rights of individual family members against one another. And although contractual terms may once have set the limits of obligations between contracting parties, the development of tort liabilities beyond the express terms of the contract-especially in the field of professional/client relationships-has redefined the legal consequences of those relations. Even earlier, reliance notions altered party control over the legal terms of relationships. For strangers, the growth of strict liability and the transformation of products liability law have significantly tightened the connections imposed by law.

101. Product liability rules transcend the boundaries between producers and victims, and make producers view potential victims as unavoidably connected to their own decisions. See generally G. CALABRESI, supra note 100.

102. One problem, however, is the question of what constitutes a community. Many communities may be present within one geographic area, or no community may exist at all in the sense that people do not experience themselves as members in a collective enterprise of mutual interdependence. These are serious issues that deserve exploration. Yet, they do not undermine the particular assertions that the adoption and use of legal language affirms and recreates particular notions of community, reinforced through the institutions of law. It is the distinction and possible disjunction between language and the institutions of law that present the more serious challenge to this analysis. See infra Section II. 
accepting or rejecting particular claims. Yet even these acts of judicial power connect words to relationships, and individuals to other individuals in complex ways. Judicial acts enable subsequent claims to be made while also allowing formal and informal resistance to the very boundaries enunciated by the court. ${ }^{103}$

The invocation of community implied by rights claims does not force individuals or subcommunities to lose their own boundaries, or to merge into the larger community. Some rights, as defined in their specific content, articulate boundaries protecting individuals or groups against connections with others. Rights against assault, for example, such as a child's right not to be subject to physical abuse, are not exceptions to the notion of rights as tools of communal dialogue. Historically, these are not exceptions but products of precisely the kind of communal inquiry I am suggesting. Through litigation and legislation, such rights have been articulated and enforced. That the particular content of the enforceable right summons members of the community to respect boundaries within the community is a commitment to implement the decisions reached through community discussion. ${ }^{104}$ Rights that recognize boundaries underscore communal ties for it is through reference to each other that we establish and articulate our boundaries. ${ }^{105}$ When I experience a sense of constraint because another claims a right, even if I reject the boundary he or she seeks to draw, I also experience connection to that person, through the process of mutual recognition.

The language of rights helps people to articulate standards for judging conduct, and the nature of rights discourse as a language for expressing meaning persists even beyond its use within legal institutions. ${ }^{108}$ In our

103. See, e.g., E.P. Thompson, Whigs and Hunters: The Origin of the Black Act (1975) (discussing rights consciousness and people's resistance to law); Forbath, Minow \& Hartog, Introduction: Legal Histories from Below, 1985 Wis. L. Rev. 759 (same).

104. Cornell, Should a Marxist Believe in Rights?, 4 PRAxIS INT'L 45 (1984) (discussing Habermas). Imposition of views, obligations, or rights from authorities above is not communal discourse, but even when litigants are essentially submitting to the higher authority of the court, the litigants' own experiences before the court may help promote a sense of their connections to each other.

105. Traces of Self-Government, supra note 52, at 32 (discussing "intersubjective" constitution of individuals in which identities and social involvements are inseparable); see also Cornell, supra note 92 , at 360-68.

106. Sartre's and Wittgenstein's notions of language are especially critical to my understanding here. Sartre describes language, not as a set of rule-bound meanings, but as a mode of human action and creative self-expression. J.P. SARTRE, BEING AND Nothingness 559-707 (H. Barnes trans. 1956). Wittgenstein emphasizes that the meanings of words are determined by their use, and that their use depends on their context, situated in forms of life, which contributes to a view of language as necessarily intersubjective and communal. See supra note 73 . I mean to invoke rights, not merely as vocabulary, but as a language in the senses implied by Sartre and Wittgenstein. In this manner, I use the analogy between language and rights much as Fred Dallmayr identifies relations between language and politics. F. Dallmayr, LANGUAGE aND Politics 174-92 (1984) (language and politics interact and mutually construct each other); $c f$. J. KAGAN, THE NATURE OF THE CHILD 112-53 
culture, even children often find rights rhetoric familiar and well-suited to express their feelings. ${ }^{107}$ And people use rights and claims to particular freedoms or entitlements to refer to what they perceive as their due even when the formal legal apparatus has not acknowledged or approved of those perceptions. ${ }^{108}$ People speak spontaneously of rights, far from legal institutions. For example, they make assertions of entitlement, need, and wants when they collide at the bus stop or on the playground. Children, no less than adults, can participate in the legal conversation that uses rights to gain the community's attention. ${ }^{100}$ If one of the problems with rights for children is that they expose children's interdependence with other people-and the conflicts engendered by that interdependence-then this is a problem for adults as well. ${ }^{110}$

Obvious examples of the interdependence of adults arise in the family context. Even when a conflict is never likely to go to court, adults in a family reveal their interdependence as they discuss such questions as: Who will run which errands? Who will take care of the children this afternoon? Who will have time to be alone? Converting these questions into conflicting claims of autonomy misses the point that shared lives are implicated by each question.

When the rights claims reach official attention, the interdependence of the claimants is no less palpable. An adult woman's right to choose to terminate a pregnancy without spousal consultation or consent clearly implicates and modifies the claims of the father, or of the potential child. Similarly, a contrary right of the father to consult or consent would implicate and modify the rights of the mother and of the potential new life. Whatever the rules, whether they criminalize such conduct or immunize it from police and prosecutorial action, the law articulates a pattern of rights that speaks to relationships among individuals even when a particular in-

(1984) (describing development of standards for judging content as part of children's growth). But see C. GREenhouse, PRAYING FOR JUSTICE 106-41 (1986) (describing Baptist community's resistance to rights and preference for harmony and cooperation as their conception of human relationships).

107. See Statement of Alvin Poussaint, Assoc. Prof. of Psychiatry, Harvard Medical School, in Television, Children, and the Constitutional Bicentennial: A Report by Action for Children's Television 34-35 (P. Charren \& C. Hulsizer eds. 1986): "I think children do understand the idea of equality and individual rights, but I think a direct connection between their lives and the Constitution has been missing in the way we educate them ...."

108. See, e.g., Forbath, The Ambiguities of Free Labor: Labor and the Law in the Gilded Age, 1985 WIS. L. REv. 767, 801-17; Matsuda, Looking to the Bottom: Critical Legal Studies and Reparations, 22 HARv. C.R.-C.L. L. REv. 323 (1987); Williams, supra note 59, at 417 ("Where, however, one's experience is rooted not just in a 'sense' of illegitimacy but in being illegitimate, in being raped, and in the fear of being murdered, then the black adherence to a scheme of negative rights-to the self, to the sanctity of one's own personal boundaries-makes sense.").

109. Both children and adults may need representation by others in this debate, and representation is problematic, but not uniquely so for children. See infra text accompanying notes 114-19 (discussing problems of attorney-client relationship).

110. I explore this at greater length in Minow, Rights for the Next Generation, supra note 30, at 15-18. 
dividual's right is declared the winning claim. A woman's right to control her own procreative choice, once announced and enforced by legal authorities, remakes a woman's relationships and alters her power, but not because law has suddenly "intervened" where it previously was absent. The law always prescribes consequences for particular relationships, even by its inaction. ${ }^{111}$ In the past, the law intervened by granting legal authority over procreative decisions to potential fathers and doctors. ${ }^{112}$

Similarly, the rights of shareholders implicate their relationships to management and workers. The rights of trust beneficiaries implicate their relationships with trustees and donors. Each statement of an individual's rights implicitly or explicitly draws reference to others, and thus, expresses relationships and interconnections at the very moment that the individual asserts his or her autonomy. In this respect, children's rights are no more problematic than adults' rights because all rights claims imply relationships among members of a community.

A familiar objection to this argument emphasizes differences between children and adults. I am rejecting here the notion that our society should answer questions about children's legal status simply by asking how children differ from adults. This question wrongly suggests that such differences are real and discoverable rather than contingent upon social interpretations and choices. According to one interpretation, children are relatively powerless, and that is why they should be treated differently than adults. One response to this view is that power itself is a quality of relationships, not a quantum or a characteristic intrinsic to an isolated person. Rights language is one type of rhetoric with which to articulate, challenge, and hold to account relationships of power. Children, no less than adults, are implicated in these relationships.

Another form of the same view emphasizes the problems of children's knowledge and competence. We adults do not trust anyone who claims to speak for a child to represent truly that child's interests in the same way we trust a representative for a competent adult. A child's representative may act either as a mouthpiece for a child, who is capable of expressing a view, or instead as a guardian, who supplies her or his own view of the child's interest. ${ }^{113}$ There are immediate grounds to distrust the adult's po-

111. This was a central insight of the legal realists. See Cohen, Property and Sovereignty, 13 CoRnel. L.Q. 8, 11-12 (1927); Hale, Coercion and Distribution in a Supposedly Non-Coercive State, 38 Pol. Scl. Q. 470 (1923).

112. See Minow, Beyond State Intervention in the Family: For Baby Jane Doe, 18 U. Mich. J.L. REF. 933, 946-53 (1985); Olsen, supra note 46.

113. Note, Lauyering for the Child: Principles of Representation in Custody and Visitation Disputes Arising from Divorce, 87 YALE L.J. 1126, 1138-53 (1978) (discussing alternative roles for children's attorneys). The problems of defining lawyers' proper roles are rivaled only by the ethical dilemmas presented when lawyers retreat behind their "roles" to justify their conduct. See Postema, Moral Responsibility in Professional Ethics, 55 N.Y.U. L. REv. 63 (1980); Rhode, Ethical Perspec- 
sition in either circumstance. The adult who offers the child's view, unmediated, may advance an irrational or misguided position; the adult who supplies a preference other than the child's has no obvious tether and lands in the thicket of general uncertainty about what is good for the child.

One response is that this charge applies to lawyers representing adult clients as well. ${ }^{114}$ The lawyer for the adult who does only what the client wants may well encounter criticism for failing to advise a different strategy. ${ }^{115}$ Yet, the lawyer who acts on her or his own view also provokes criticism from observers. ${ }^{116}$ The problem of distrusting lawyers' interpretations of clients' interests is well-known in public-interest litigation. ${ }^{\mathbf{1 1 7}}$ The issue becomes particularly apparent when the lawyer works for a large organization, like a law firm, that has its own interests, distinct from those of the clients. ${ }^{118}$ Yet the difficulty seems inherent in the legal representation of any client:

The problem of insuring that advocates work towards the best inter-

tives on Legal Practice, 37 Stan. L. Rev. 589 (1985).

114. This objection also applies to judges. See Kennedy, Distributive and Paternalist Motives in Contract and Tort Law, with Special Reference to Compulsory Terms and Unequal Bargaining Power, 41 MD. L. REv. 563 (1982).

115. See, e.g., Crouch, Divorce Mediation and Legal Ethics, 16 FAM. L.Q. 219, 224-34 (1982) (risks to clien when left without independent legal advice); Nelson, Ideology, Practice, and Professional Autonomy: Social Values and Client Relationships in the Large Law Firm, 37 STAN. L. REV. 503 (1985) (arguing that there is little evidence that corporate lawyers serve to restrain and challenge clients' actions); Wasserstrom, Lauyers as Professionals: Some Moral Issues, 5 Hum. RTs. 1 (1975) (role-differentiated character of lawyers' situations alters relevant moral point of view); $c f$. Kraakman, Corporate Liability Strategies and the Costs of Legal Controls, 93 YALE L.J. 857, 888 (1984) (discussing inducement of corporation members to act as gatekeepers monitoring corporate wrongdoing).

116. The most elaborate criticism appears in discussions of class actions. See Bell, Serving Two Masters: Integration Ideals and Client Interests in School Desegregation Litigation, 85 YALE L.J. 470 (1976); Rhode, Class Conflicts in Class Actions, 34 STAN. L. REv. 1183 (1982). Yet charges have been levied against lawyers representing individual adult clients as well. See, e.g., Burt, Conflict and Trus, - $n$ Attorney and Client, 69 GEO. L.J. 1015 (1981) (discussing distrust in attorneyclient relatio. ）; Luban, Paternalism and the Legal Profession, 1981 WIS. L. REv. 454 (discussing when pat. alism is and is not justified); see also Fried, The Lawyer as Friend: The Moral Foundations o, the Lawyer-Client Relation, 85 YALE L.J. 1060 (1976) (responding to charges that lawyer's role as advocate incompatible with moral values).

117. Some may argue that adult clients in public-interest litigation can hire and fire, and therefore control, their attorneys. See Mnookin, The Paradox of Child Advocacy, in IN THE INTEREST of CHILDREN, supra note 30, at 53-55. This hardly seems compelling when the client group is large and individual members have little control, when the litigation is complex and not easily explained to clients, or when the members of a class action have potential conflicts. See id. at 54.

118. See Nelson, supra note 115 , at 465 (institutional factors at both law firm and societal levels influence lawyers' representation of clients); Food For Thought: Case Study, Harvard Program on the Legal Profession (unpublished manuscript on file with author) (exploring lawyer's conflicting concerns with firm's reputation in Food and Drug work and needs of particular client); see also D. Rosenthal, LAWYer AND Client: Who's IN GhaRge? 96-105 (1974) (discussing conflict between lawyer's financial interests and client's interests); Blumberg, The Practice of Law as a Confidence Game, 1 LAw \& Soc'y REv. 15 (1967) (conflicts between criminal defense lawyers' ongoing commitment to organization of criminal process and obligations to particular client). 
ests of the client is inherent in any system which uses counsel to represent clients. Where one party is given the authority to put forward another's interests, there is always the danger that the agent will not be faithful to the interests of his client. The agent may have misperceived what the client wanted. The agent may believe something to be in the client's interests when it actually is not. Finally, wherever power is delegated, there is always the potential and incentive for the agent to put his own interests ahead of those of his client. These problems infect almost every human relationship. ${ }^{110}$

Children are often less articulate and less self-knowing than adults, but these qualities need not render them peculiarly vulnerable within a legal system. If there are reasons to distrust legal representatives of children, there are reasons to distrust legal representatives of adults, and confronting both kinds of distrust may demand more, not less, legal conversation. Courts could appoint multiple representatives to offer contrasting views of children's rights and interests, ${ }^{120}$ or else demand fuller exploration by the initial representatives of the range of interests potentially involved in the litigation. The court has long been assigned the special task of guarding the interests of children in litigation; what may be missing are practical steps to prepare the court to fulfill this job.

There is a second objection to conceiving of children's rights and adults' rights as similar. Children's economic, physical, and emotional dependence on adults seem different in scale than adults' needs. Articulating children's interests in terms of rights arguably risks undermining the relationships through which those needs are usually met. ${ }^{121}$ This objection assumes that children would be better off if schools and families were removed from the purview of public scrutiny permitted by rights claims.

Although I would readily agree that public review itself may damage some children and disturb the adults who care for them, ${ }^{122}$ there often are

119. Mnookin, supra note 117 , at 54 .

120. See Chambers \& Wald, supra note 64, at 144 (recommending appointment of additional counsel to offer contrasting perspectives in test case litigation involving children).

121. Alternatively, expressing the needs of children through rights rhetoric presents greater difficulties in setting limits on those claims than do adults' claims. See Goss v. Lopez, 419 U.S. 565, 597 (1975) (Powell, J., dissenting) (difficulty drawing lines for children's rights); Burt, supra note 84, at 265. This objection, however, stems from a mistaken view that rights have defined limits, which has hardly been the case in other areas, such as toxic tort and prison reform litigation. In those contexts, as in legal challenges to foster care, institutional treatment, and other systems handling (and mishandling) children, the legal processes of argument, negotiation, and monitoring can orchestrate claims and remedies.

122. See Avery, The Child Abuse Witness: Potential for Secondary Victimization, 7 CRIM. Just. J. 1 (1983) (discussing potential harms to child from participation in prosecution); Myers, The Legal Response to Child Abuse: In the Best Interest of Children?, 24 J. FAM. L. 149 (1985-1986) ("goal of protecting children often disserved by litigation"); $c f$. S. ESTRICH, REAL. RAPE (1987) (harm to adult rape victim imposed by criminal justice system); Nemeth, Legal Emancipation for the Victim of Rape, 11 Hum. RTs. 30 (1984) (same). 
more serious risks to children if the adults who care for them are free from public review. ${ }^{123}$ When the state deems "at risk" individual children who are disproportionately members of minority racial groups and the poorest sectors of the society, claims of rights on their behalf represent efforts to rectify larger social patterns that damage people. ${ }^{124}$ The image of rights as damaging and weighty instruments that should be reserved for adults is only one possible conception of rights. My alternative conception emphasizes rights as a language that can express and remake patterns of all relationships. ${ }^{125}$

As a language recognized by official legal institutions, rights rhetoric bears traditional meanings, but it is capable of carrying new meanings. Even rights as rules represent past legal consequences, or asserted consequences, of certain existing social, economic, and political relationships. The struggle among competing groups, and the struggle to establish affiliations away from and perhaps different than those of the majority, present larger questions of relationships in terms of rights. What rights and patterns of rights can protect groups when their norms conflict with those countenanced or enforced by the official legal system ${ }^{2128}$ These are among the most difficult questions for a diverse and discordant society, but, in addressing them, rights discourse has proven to be both pliant and meaningful.

\section{Why Talk About Rights, Anyway?}

Why advance this conception of rights, including children's rights, as a vocabulary used by community members to interpret and reinterpret their

123. The rates of child abuse are difficult to estimate, but observers now agree that the problem is widespread, and relatives and friends, not strangers to the child, are by far the most common perpetrators. See Conte, The Justice System and Sexual Abuse of Children, 58 Soc. Service Rev. 556, 557-58 (1984) (reporting one study in which 38\% of adult women respondents reported that they had been sexually abused as minors and another study where $47 \%$ of perpetrators are members of child's own family and $42 \%$ are known to child but are not family members); Fuller, Child Abuse Rises, 72 A.B.A. J., Feb. 1986, at 34 (reporting study estimating 1.793 million abused and neglected children in 1985); ten Bensel, The Scope of the Problem, 35 Juv. \& FAM. CT. J. 1, 1-2 (1984) (estimating that under broad definition 4 to 5 million children per year are neglected and/or abused, and noting dramatic increase in reporting of sexual abuse).

124. See Solnit, Children, Parents, and the State, 52 Am. J. Orthopsychiatry 496, 501-04 (1982) (critique of increased state intervention into family life through mandated reporting of child abuse and refusals by state to return children whom parents initially placed voluntarily with state); see also Krisberg \& Schwartz, Rethinking Juvenile Justice, 29 CRIME \& Del.INQ. 333 (1983) (summarizing data and policy developments in juvenile justice); Pope \& Feyerherm, Race and Juvenile Court Dispositions: An Examination of Initial Screening Decisions, 8 CRIM. JUST. \& BEHAV. 287 (1981) (study of racial impact of juvenile court practices).

125. Cf. M. BALL, supra note 21, at 132-33 (rejecting conception of courtrooms as setting for battle and replacing it with metaphors of theatre, dance, and dialogue).

126. See Nomos and Narrative, supra note 23, at 60-68; Levinson, Constituting Communities Through Words That Bind: Reflections on Loyalty Oaths, 84 Mrch. L. REv. 1440, 1447-48, 1454-56 (1986). 
relationships with one another? This conception responds both to those who criticize newly articulated rights for lacking objective foundations and to those who criticize rights for their analytic indeterminacy. By analogizing rights to language, and treating rights as a particular vocabulary implying roles and relationships within communities and institutions, this approach suggests how rights can be something-without being fixed, and can change-without losing their legitimacy. ${ }^{127}$

Rights are hardly neutral. With them, we pick from among a variety of possible legal consequences for human relationships, and thereby influence the pattern of existing and future relationships. ${ }^{128}$ Moreover, the interpretive turn, as described in this essay, pins law not on some force beyond human control, ${ }^{129}$ but on human responsibility for the patterns of

127. Ball quotes Thomas Reed Powell, who in turn quoted one James Beck, on a metaphor for the Constitution that struggled similarly to conceive of law somewhere between fixity and fluidity:

'The Constitution is neither, on the one hand, a Gibraltar rock, which wholly resists the ceaseless washing of time and circumstance, nor is it, on the other hand, a sandy beach, which is slowly destroyed by the erosion of the waves. It is rather to be likened to a floating dock, which, while firmly attached to its moorings, and not therefore at the caprice of the waves, yet rises and falls with the tide of time and circumstance.'

M. BaLl, supra note 21, at 18 (quoting Powell, Constitutional Metaphors (Book Review), NEw Republic, Feb. 11, 1925, at 314); see also R. Cover, Justice Accused 126-30 (1975) [hereinafter JUSTICE ACCUSED] (discussing language and rules). Cover notes:

There are those who speak law-language poorly-whose departures from the rules will not live; who reflect neither the wave of the future to be washed into prophecy by the acceptance of the masses nor the compelling idiosyncratic departure of the master, which will pull the masses after it. Others-the vast majority-speak according to the rules, for the rules are largely derived from such as these. They depart occasionally, usually inadvertently. Then there are prophets and masters who move the law more than their democratic, per-capita share. Either they evoke the response: "This is what we've known or wanted all along, but never before so articulated." Or they strike the chord: "We've rejected or never thought of this before, but your argument compels attention, even conviction."

Id. at 128. And:

When there is a departure from the rules, however, that which determines whether the rules have been changed is not so much another rule determining changes in rules as it is the acceptance of the change by others over time. In this respect the language analogy is far better than Id. the extended game analogy [as a way to understand law].

128. Claims of rights that call for negotiation, consultation and, indeed, discussion as ways to handle disputes cannot be neutral: They call for recognition of each disputant by the other. When the Children's Hearings Project in Cambridge, Massachusetts receives parental complaints diverted by the Juvenile Court about "unruly" children, the Project staff creates opportunities for parents and their children to negotiate contractual agreements to resolve their disputes, and to establish procedures for future disputes. This non-neutral approach demands that the parents take their children's complaints as seriously as their own, even though the particular contracts negotiated by the family members depend upon their own views, not those of the Project staff. S. Merry \& A. RocheleAu, Mediation in Families: A Study of the Children's Heafing Project 91-101 (1985).

129. See J. NoONAN, The Antelope: The Ordeal of the Recaptured Africans, in THE ADMINISTrations of James MONRoe and John Quincy Adams 159 (1977):

Those who suppose that the legal system is a self-subsistent set of rules existing outside of its participants and constraining lawyers and judges to act against their consciences will always be prevalent among lawyers, judges and legal historians. . . . But every so often in a human heart the ice will crack, and a human person will acknowledge his responsibility for other human persons he has touched. 
rights and rules that emerge from legal discourse and from the human relationships promoted or hindered by this process. In this way, the notion of rights as tools in continuing, communal discourse helps to locate responsibility in human beings for legal action and inaction. ${ }^{130}$ The interpretive framework seeks to reinvest legal activity with a believable aspiration to create communal meaning amid a world scarred by justifiable skepticism. ${ }^{131}$

\section{Cover's Challenge: Violence and the Word}

[Truth] excludes the use of violence because man is not capable of knowing the absolute truth and therefore is not competent to punish.

The townspeople perceive the equation of word and law, how Joe's big voice commands obedience: "You kin feel a switch in his hand when he's talkin' to yuh."

-Elizabeth Meese $e^{133}$

Robert Cover described the "recent explosion of legal scholarship placing interpretation at the crux of the enterprise of law."134 Indeed, his own work eloquently portrays legal scholarship as the study of a "normative

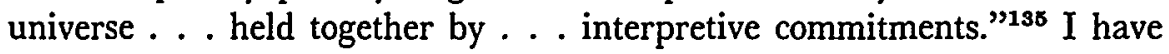
relied on Cover's work as exemplary of the ways people elaborate normative commitments through interpretive activities. ${ }^{136}$ Yet, in an essay published after his death, Cover raised a warning that should chill those of us who are taken with the interpretive turn in law. He warned that an interpretive stance fails to acknowledge that "[l]egal interpretation takes place in a field of pain and death." ${ }^{132}$ When judges interpret texts, "somebody

130. A similar purpose animates another work by John Noonan, who took three cases and probed beneath the labels of legal analysis and roles to find the persons and lines of responsibility routinely suppressed. J. Noonan, Persons and Masks of The Law, supta note 80; see also J. Noonan, supra note 129; JuSTICE ACCUSED, supra note 127 (exploring jurisprudential and psychological reasons why judges opposed to slavery nonetheless enforced Fugitive Slave Laws).

131. Cover described interpretive work as "an attempt to hold a worthy ideal before what all would agree is an unredeemed reality." Violence and the Word, supra note 7, at 1628.

132. Quoted in E. ERIKSON, GandHI's TrUTH 241 (1969).

133. E. Meese, Crossing the Double-Cross: The Practice of Feminist Criticism 46-47 (1986) (quoting Zora Neale Hurston) (discussing Z. Hurston, TheIR Eyes Were Watching GoD 602 (1978)).

134. Violence and the Word, supra note 7, at 1601-02 n.2.

135. Nomos and Narrative, supra note 23 , at 7.

136. See supra text accompanying notes 23-24.

137. Violence and the Word, supra note 7, at 1601. 
loses his freedom, his property, his children, even his life."138 Judicial interpretation often supplies rationales for violence that has occurred or will occur. ${ }^{139}$ Legal scholars interested in interpretation systematically ignore or suppress how law is steeped in violence and social control. ${ }^{140}$ " $\mathrm{A}$ legal world is built only to the extent that there are commitments that place bodies on the line."141 Official power effectuates itself in physical force, threatened or carried out. Human responses to that force also express interpretations, including compliance to rebellion, resistance, and martyrdom. Steeped in the state's own violence even in responding to it, resistance and martyrdom are interpretive acts, creating normative worlds with legal consequences. But these acts are ignored in accounts of law as interpretation. Fundamentally, law embeds interpretations of political texts in institutions that exercise the state's monopoly over legitimate violence: Law organizes not just meaning, but also power. ${ }^{142}$ Thus, legal scholars should pay attention not only to judicial rhetoric, but also to judicial action, to the real effects of judicial action, and to the ways that legal language and meaning are inescapably bonded to institutionally implemented deeds. ${ }^{148}$

Gover is right. His is a devastating and haunting insight. Judges may use words and interpret texts, but their words organize and justify official acts of power. Those acts hurt some people and help others. The threat and fact of the force behind judicial acts shatter the image of normative community and nurturing dialogue embraced by interpretive legal scholarship. The rhetoric, uttered amidst the wielding of power, makes more palatable what might otherwise have been noxious. ${ }^{144}$

Cover's challenge alters the terms of the debate and for someone, like me, who is drawn to the interpretive turn, his challenge forces reconsideration and reevaluation. Legal scholars may have turned to the interpretive frame, which holds up a vision of communal efforts to create meaning, in an effort to demystify law and to rid it of its aura of objectivity. The

138. Id.

139. Id.

140. Id. at 1602 n.2.

141. Id. at 1605 .

142. Id. at 1602 n.2, 1605. This insight also may explain Cover's fascination with the intriguing possibility of severing the link between law's normative dimension and its organization of power, as in the creation of courts without official authority. See Folktales of Justice, supra note 25, at 200-02.

143. Violence and the Word, supra note 7, at 1609, 1617-18; see also The Bonds of Constitutional Interpretation, supra note 7, at 817-31 (describing institutional framework within which judicial violence must take place).

144. The use of law to legitimate the exercise of power has been the subject of much scholarly discussion, see, e.g., E. Genovese, Roll, Jordan, Rol.l 25-49 (1974); D. Hay, Property, Authority and the Criminal Law, in Albion's Fatal Tree: Crime and Societr in Eighteenth-Century England 17, 56-63 (1975); M. Polanyi, Personal. Knowledge 222-33 (1958); E.P. THOMPSON, supra note 103, at 258-69, and some scholarly dispute, see Hyde, The Concept of Legitimation in the Sociology of Law, 1983 Wis. L. REv. 379. 
interpretive frame, however, poses the danger of a new mystification, one that casts an aura of cozy conversation over official acts of domination and control. ${ }^{145}$ This new mystification is dangerous if it obscures an insight that, as Cover explains, has been exposed by many social scientists, if not by history itself: "Persons who act within social organizations that exercise authority act violently without experiencing the normal inhibitions or the normal degree of inhibition which regulates the behavior of those who act autonomously." 148 The ways individuals grow numb to their own exercises of power and infliction of pain may be especially pronounced when they act in roles that "separate[] the act of interpretation-of understanding what ought to be done-from the carrying out of this 'ought to be done' through violence."147 For example, our legal system assigns one person to impose a criminal sentence and another to implement it. ${ }^{148}$ The involvement of so many official actors actually may limit the state's exercise of violence: "[N]o single mind and no single will can generate the violent outcomes that follow from interpretive commitments." 149

Nonetheless, applying the language of interpretation to legal action poses a danger of "exaggerating the extent to which any interpretation rendered as part of the act of state violence can ever constitute a common

145. Cover notes that violence is intrinsic to the practice of law and government. For example, there is no need to authorize government to practice violence. In addition, powers of violence are explicitly granted to governments by texts, such as the "Power to . . . provide for the common Defence," U.S. ConST. art. I, $\S 8, \mathrm{cl}$. 1, and the power "To provide for the Punishment of counterfeiting," U.S. CoNST. art. I, § 8, cl. 6. Violence and the Word, supra note 7, at 1610 n.22.

146. Violence and the Word, supra note 7, at 1615 (discussing work of Stanley Milgram, Anna Freud, and Konrad Lorenz); see Traces of Self-Government, supra note 52, at 14-16, 35, 76; Sloan, Death Row Clerk, NEw REPuBLIC, Feb. 16, 1987, at 18 (describing death penalty work of Supreme Court Justices and their clerks). 52:

147. Violence and the Word, supra note 7, at 1627; see Traces of Self-Government, supra note

Clearly, then, adoption of the imperial stance with respect to a particular case, or kind of case, can and therefore ought to be a judicially responsible act. Still there remains in that stance, whenever adopted, some element of flight from responsibility or from what Robert Cover called "commitment." "Objective" legal standards seem to absolve judges of responsibility for the fates of individual parties. "Neutral" legal standards seem to absolve their promulgators-sometimes the very judges who apply them-of responsibility for their contributions to socially unequal or conflictual outcomes. Accordingly, a judge's commitment to imperial responsibility also involves a certain withholding of commitment. In this circumstance lies the pathos of the judicial role, and its irony, which Robert Cover expressed in the ironic label he gave it: "The jurispathic office."

Id. at 15 (citations omitted).

148. Even beyond institutional roles and separations of functions, law legitimates a flight from responsibility by giving "deference" to decisions made by those in power and by relying on language so formal and distant that what is at stake remains far from view. In linguistic sleights-of-hand, lawyers and judges invent fictions to persuade and to disguise what they do, and legal scholars justify the "utility" of these tactics. The master work is still probably L. Fuller, LEGAL FICTIONS (1967), reprinted from Fuller, Legal Fictions (pts. 1-3), 25 ILL. L. REv. 363, 513, 877 (1930-1931). For a probing inquiry into the subject, see Soifer, Reviewing Legal Fictions, 20 GA. L. REv. 871 (1986).

149. Violence and the Word, supra note 7, at 1628; see The FeDeralist No. 51 (J. Madison) (separation of governmental powers in departments with means to resist encroachment by others as design for promoting liberty). 
and coherent meaning."180 The language of interpretation pretends that judges and litigants share a world, when in fact judicial authority irradicably divides their worlds. Cover also warns that interpretive rhetoric is especially dangerous if it hides differences or papers over clashes between normative commitments in and between communities in the name of state authority. An equivalent danger arises if interpretive rhetoric smooths away the gripping points of leverage against official power, eliminating the contrasting rhetoric of fundamental social conflict, class warfare, and the state's hegemonic power. An interpretive turn emphasizing communal connections in the acts of interpretation risks washing away these points of external critique by implying an internal commonality, or by scoffing at charges of exclusion with assertions of universal inclusion. Thus, the very way that interpretation responds to charges that law creates conflict-the response that involves communality-may obscure enduring conflicts within and beyond a legal dispute.

What, then, are the consequences of Violence and the Word for interpretive legal scholarship? Cover interprets his own message as at once partially reassuring and perpetually disturbing. On the one hand:

It would not be better were there only a community of argument, of readers and writers of texts, of interpreters. As long as death and pain are part of our political world, it is essential that they be at the center of the law. The alternative is truly unacceptable-that they be within our polity but outside the discipline of the collective decision rules and the individual efforts to achieve outcomes through those rules. ${ }^{151}$

And on the other:

[A]s long as legal interpretation is constitutive of violent behavior as well as meaning, as long as people are committed to using or resisting the social organizations of violence in making their interpretations real, there will always be a tragic limit to the common meaning that can be achieved. ${ }^{152}$

Because law involves state control over organized violence, legal interpretation is inextricably entwined with violence. Because people seek to make their own meanings real in terms governed by officially organized forms of violence, legal translations of interpersonal and group conflict are inevitably bound up with violence. And because these patterns gird mean-

150. Violence and the Word, supra note 7 , at 1628 .

151. Id.; see The Bonds of Constitutional Interpretation, supra note 7 , at 827 .

152. Violence and the Word, supra note 7, at 1629. 
ing-making with violence, common meaning, truly shared, can never be attained. Violence inevitably constitutes law and the conflicts in law's arenas. With every effort not to blink at this reality, I intend to consider the broad inquiry that Cover's work opens into the relations between violence and law. His inquiry does not require abandoning the interpretive framework but instead invites us to aim it, steadily, critically, toward the connection between meanings and power. ${ }^{153}$ In this sense, I mean to pursue the insights of Violence and the Word further, and to pursue them with an interpretive method exemplified by Robert Cover's work, even if this method challenges, or misinterprets, aspects of his claims.

\section{A. The Meanings of Violence}

It is dangerous to disguise the violence actually commanded and sanctioned by law with the rhetoric of justification offered by judges, scholars, and other interpreters. Yet, it is also dangerous to treat all legal meanings as reducible to state organized violence. The contexts of violence and the relationships among actors and agencies imbue official power with varieties of meanings. In particular, the meaning of violence changes when it is used to challenge other violence.

Some legal interpretations help people place limits on government power. Granted that each recourse to law, in some fundamental way, reconfirms the power of the state, ${ }^{154}$ the creation of normative language to rationalize the exercise of state power can redound to support human pressures to limit that power. ${ }^{155}$ Legal language has force. It both triggers and justifies power. But precisely because language is not identical to power, people may at times use it as a brace against power. ${ }^{158}$ Whatever

153. Interpretation, as I mean it here, should be practiced as a critical, that is, self-critical, theory. See R. Geuss, The Idea of a Critical. Theory (1981) (developing critical theory); M. Ryan, Marxism and Deconstruction (1982) (same); J. Thompson, Critical Hermeneutics: A Study in the Thought of Paul Ricoeur and Jurgen Habermas (1981) (same); M. Walzer, INTERPRETATION AND Social CRITICISM (1987) (same).

154. See, e.g., Gabel \& Harris, Building Power and Breaking Images: Critical Legal Theory and the Practice of Law, 11 N.Y.U. Rev. L. \& Soc. Change 369, 375 (1982-1983); Kennedy, Critical Labor Law Theory: A Comment, 4 Indus. ReL. L.J. 503, 504 (1981). But see Fiss, Why the State?, 100 HARv. L. REv. 781 (1987) (arguing that state involvement in enforcing First Amendment is only alternative to dangers of oppression of many by the few).

155. Similarly, a parent who offers a justification for action supplies the child with a basis for challenging future action: "But you said ...."

156. There is a debate about what kind of independent constraining power is ever produced by legal-or moral-rhetoric invented or invoked to justify power's exercise. Compare, C. REMBAR, ThE Law of The LAND: The Evolution of OUR Legal System 212 (1980) (common law enabled king to enlarge royal jurisdiction-but common law also constrained king "because the supremacy of the common law [was] a supremacy over everyone, including the monarch himself. The kings had made a monster that devoured them.") with M. PolanyI, Personal Knowledge 226-27 (1958) (language of morality accompanies power in all complex societies, but hardly survives with independence). 
action follows a judicial decision, the decision and its rationale, unlike brute force, allow for later interpretation and reinterpretation. The meanings set in motion by justificatory legal language add meanings to judicial violence and even provide vantage points for criticizing it.

Judicial violence can mean the force and power used to effectuate state regulation. Some of that violence may destroy private activities or private meanings_-but, as Cover wrote, "[v]ery often the balance of terror in this regard is just as I would want it." "157 Some judicial violence may reinforce patterns of domination and exclusion otherwise persisting in society. Here, the meanings of judicial violence take on the prejudices of private factions. Thus, the violence ordered by the state takes on different meanings in different contexts.

Moreover, judicial inaction can be violent. ${ }^{158}$ Thus, it would be a mistake to treat judicial inaction as always preferable to judicial action. Judges do violence when they fail to respond to suspected spouse or child abuse for fear of disrupting-doing violence to-family bonds. Judges do violence when they leave in place a neglectful system for providing substitute care when parents fail, and expose dependent children to physical and emotional damage. ${ }^{158}$ The focus on judicial acts as the link between legal meaning and legal violence should not obscure the continuing presence of legal control and state-approved force in the lives of both children and adults. Violence condoned by the state and ordered by the state may differ, but interpreting the meaning of either discloses the shared fact of violence.

Private authorities also exercise power and violence. The meanings of private violence, too, can and must be interpreted; such interpretation can expose the violence that has been hidden under other labels. Some actions by parents, husbands, school officials, creditors, gangs, murderers, and corporate managers are, under analysis, undeniably violent. ${ }^{180}$ But, the

157. Violence and the Word, supra note 7, at 1608. Cover continued: "But I do not wish us to pretend that we talk our prisoners into jail." Id.

158. Cover is attentive to this in his Georgia essay, but he also emphasizes the citizen's deeds as necessarily violent actions that convey meanings capable of interpretation:

In law to be an interpreter is to be a force, an actor who creates effects even though or in the face of violence. To stop short of suffering or imposing violence is to give law up to those who are willing to so act. The state is organized to overcome scruple and fear. Its officials will so act. All others are merely petitioners if they will not fight back.

The Bonds of Constitutional Interpretation, supra note 7, at 833.

159. See, e.g., K. Wooden, Weeping in the Playtime of Others: America's IncarcerATED CHILDREN 47-57 (1976) (describing Charles Manson's harrowing journey through temporary custody arrangements and institutions during childhood).

160. See Hale, Law Making by Unofficial Minorities, 20 Colum. L. Rev. 451 (1920) (exploring power wielded by private parties imposing constraints like those imposed by public power); Lynd, Towards a Not-for-Profit Economy: Public Development Authorities for Acquisition and Use of Industrial Property, 22 HARv. C.R.-C.L. L. REv. 13, 16-24 (1987) (describing devastation of communities by plant shut-downs). 
private contexts, and symbolic meanings of these actions may obscure how such people commit violence, and whom they victimize. Children are, all too often, the unnamed victims. Parents, teachers, neighbors, and strangers exercise physical and emotional control over children and sometimes do great violence to them. These authorities often abuse, neglect, or otherwise injure children while acting within the very communities that Cover, and I, would value for their ability to generate normative commitments away from the state. ${ }^{161}$ Cover's exploration of the organization of power and meaning is pertinent not just to law, but also to other realms where authority is exercised such as families, religious communities, and schools. ${ }^{\mathbf{1 6 2}}$

Other kinds of private violence represent responses to state power and state actions. In the midst of political and social struggles, acts of violence to property and even to persons can carry meanings that advance new normative commitments, meanings that may be the roots of new rights. In part, these private acts of violence must be judged in the same way as official violence. The judgments, in each case, should include (but not stop with) efforts to interpret the meanings of the violence for those affected. Potentially violent dimensions of private power can accompany efforts to make new meanings, even meanings that may be relevant for criticizing public power.

At the same time, public officials may engage in interpretive activities that challenge exercises of private power. In so doing, they generate norms that alter the meanings of the public power. "When they oppose the violence and coercion of the other organs of the state, judges begin to look more like the other jurisgenerative communities of the world," Cover wrote. ${ }^{163}$ Historical and social contexts matter in interpreting the meanings of public and private violence. To interpret these meanings, we should ask: To what does the violence respond? What symbolic and expressive meanings may it carry? How would inaction leave other sources of violence unchallenged?

To explore the meanings of violence is to recognize that words and thoughts help constitute the world. This does not mean forgetting how the

161. See Curry \& Riley, Notes on Church-State Affairs, 26 J. Church \& State 561, 587-88 (1984) (state intervention into internal affairs of Northeast Kingdom Community Church on charges of child abuse); Note, House of Judah: The Problem of Child Abuse and Neglect in Communes and Cults, 18 U. MICH. J.L. REF. 1089 (1985) (state involvement within religious cult on charges of child abuse and neglect).

162. Along these lines, Roberto Unger has written:

[T] he family is a structure of power, ennobled by sentiment. Both as sentiment and as power, it repudiates the rule of law. Were the family mere sentiment, it would disintegrate, for according to this outlook sentiment is precarious and formless. Were the family brute power, unsoftened by sentiment, it might not merit preservation. The redemptive union of authority and affection provides the alternative to legal or at least to contractual ordering.

Unger, supra note 25, at 624 .

163. Nomos and Narrative, supra note 23, at 57-58. 
real facts of violence rip apart and destroy parts of the world. To explore the meanings of violence is to wager that violence itself is made more and less possible by patterns of meaning; that certain kinds of people become victims of violence, in part, because social meanings fail to constrain that violence; and that violence committed in the name of the state can, in part, be understood, and maybe channeled, through vigilant attention to its meanings.

Heightened efforts to expose violence and to develop more articulate understandings of its public and private forms are risky. There are risks in peeling away the cultural meanings of public and private authority from raw acts of violence. There are risks that authority will not be able to claim so ready obedience. There are risks of disturbing seemingly settled understandings about what power is, who has it, and who does not-and risks of new kinds of fights about the meanings of power and violence. But we must take these risks. Naming violence inside and outside the courtroom bears witness to it and preserves the possibility of judging it. Legal rhetoric, legal norms separated from the particular instances of their announcement, can help name and challenge both public and private violence. "Law connects 'reality' to alternity constituting a new reality with a bridge built out of committed social behavior."184

\section{B. The Power of Meanings}

Violence and the Word reminds us, relentlessly, that words do not erase violence. Judicial words may sanitize or domesticate violence. But after a judicial decision, people are thrown in prison, ordered to sell their businesses, forced to give up their children, or sentenced to lose their lives. Words should not disguise these facts. But nor should these facts disguise the power of words. There can be an important difference between legal interpretation and violence committed in law's name. Because we use legal symbols to make meaning, our interpretations of these symbols can challenge other kinds of power. Legal language itself is powerful. ${ }^{165}$

Language unconnected with official power can do violence. Pornography can devalue particular individuals. It can link sexual intimacy with

164. Folktales of Justice, supra note 25, at 181 (footnote omitted).

165. Cf. M. Edelman, Political Language: Words That Succeed and Policies That Fall (1977) (exploring how language influences public policy and politics); M. FoucaulT, The Discourse on Language, in THE ARchaEOLOGY OF KNOWLEDGE 215 app. (1972) (discussing how discourse shapes consciousness and implements authority); D. Stone, The Strategic Uses of Causation in Problem Definition 2 (unpublished paper presented at Conference on Problem Definition in Public Policy, Brown University, Oct. 16-18, 1986) (defining "problem definition" as a struggle among political actors to control interpretations and symbols); see also L. IRIGARAy, ThIS SeX Which Is Not ONe (C. Porter trans. 1985) (effort to replace male-centered language and thought); $P$. Medvedev \& M. Bakhtin, The Formal Method in Literary Scholarship (A. Werhle trans. 1978) (language as field of ideological contention yet not reducible to material interests). 
brutality, and incite violence directly or indirectly. ${ }^{186}$ Labels assigned by medical professionals can consign individuals to the scorn of others, and to the physical and emotional abuse that may follow. ${ }^{\mathbf{1 6 z}}$ When children are involved, the use of words by adults may impose direct or indirect violence. A school may label a child on the basis of educational and medical tests, with devastating consequences for the child's self-esteem, future success, and vulnerability to abuse by peers. ${ }^{168}$ Child pornography subjects individual children to actual violence and also uses their images to damage and devalue all children. ${ }^{169}$ These are simply examples of the general point. Rhetoric is linked to action and power. ${ }^{170}$

166. See Hommel, Images of Women in Pornography and Media, 8 N.Y.U. REv. L. \& Soc. Change 207 (1978-1979); Jacobs, Patterns of Violence: A Feminist Perspective on the Regulation of Pornography, 7 Harv. Women's L.J. 5 (1984); Pornography: Social Science, Legal, and Clinical Perspectives, 4 LAw \& INequality 17 (1986) (symposium); Sunstein, Pornography and the First Amendment, 1986 Duke L. Rev. 589; Zillmann \& Bryant, Pornography, Sexual Callousness and the Trivialization of Rape, 32 J. Comm. 10 (1982). But see Making Sense of Research on Pornography, in WOMEN AGAinst CENSORShIP 181 app. (V. Burstyn ed. 1985) (listing alternative views).

The circuit court that rejected the Indiana pornography ordinance nonetheless acknowledged that "[d]epictions of subordination tend to perpetuate subordination. The subordinate status of women in turn leads to affront and lower pay at work, insult and injury at home, battery and rape on the streets." American Booksellers Ass'n v. Hudnut, 771 F.2d 323, 329 (1985) (holding that Indianapolis pornography ordinance violates First Amendment). The court added: "In saying that we accept the finding that pornography as the ordinance defines it leads to unhappy consequences, we mean only that there is evidence to this effect, that this evidence is consistent with much human experience, and that as judges we must accept the legislative resolution of such disputed empirical questions." Id. at 329 n.2. See generally Russell, Pornography and Violence: What Does the New Research Say?, in TAke BACK THE Night: WOMEN ON PORNOGRAPHY 218 (L. Lederer ed. 1980) (reviewing studies); Selected Bibliography on Pornography and Violence, 40 U. PITT. L. REv. 652, 658-60 (1979) (listing studies of pornography and violence).

167. T. Scheff, Being Mentally Ill 87 (1966) (persons once labeled are forced into social role that produces ostracism); S. Gould, The Mismeasure of MaN 158-233 (1981) (discussing sterilization and mistreatment of people labeled mentally retarded); Gould, Carrie Buck's Daughter, 2 Const. Commentary 331 (1985) (same). Labelling theory suggests that changes in public attitudes about the labeled condition dramatically affect the consequences of labeling. See Gove, Labelling and Mental Illness: A Critigue, in The Labelling of Deviance 85-86 (W. Gove 2d ed. 1980) (changing public attitudes toward mental illness and treatment reduce victimization as result of labelling). See generally Minow, When Difference Has Its Home, supra note 15 (discussing labelling theory and alternative approaches to treatment of difference).

168. J. Handler, The Conditions of Discretion: Autonomy, Community, BureauCRACY 80-82 (1986) (urging use of functional labels for special education because disability labels have potentially harmful effects on children and do not link to specific programs). See generally THE LABELling of Deviance supra note 167 (W. Gove 2d ed. 1980) (evaluating sociological theory of labelling, under which assignment of deviant label itself can injure); R. PAGE, STIGMA (1984) (exploring concept of stigma in relation to assigned labels).

169. See New York v. Ferber, 458 U.S. 747, 758 (1982) (rejecting First Amendment challenge to legislation against child pornography and citing studies of harm to children); see also S. O'BRIEN, ChILd PoRNOGRaPhy (1983) (reviewing prevalence, information on perpetrators, symptoms, and ef(ects on children); $f$. Cline, Croft \& Courrier, The Desensitization of Children to TV Violence, in Where Do You DRAW THE LiNE? 147 (V. Cline ed. 1974) (effects of watching violence on children's attitudes).

170. This is at least in part because people use language to express themselves to wield and challenge authority. Even highly technical elaborations of linguistic theory and literary theory manifest and enact power struggles. See generally F. DALLMAYR, supra note 106; T. EAGLETON, LITERARY THeORY (1983); M. Foucault, Power/KnOwLedge 78-108 (C. Gordon ed. 1980). Another view emphasizes that people create themselves and their own meanings through the particular lan- 
In each of these instances, a reinterpretation of existing legal claims has effectively challenged prevailing practices. Public prosecutors have investigated disciplinary practices by parents and religious communities; ${ }^{171}$ litigators and legislators have devised participatory procedures to control the assignment of labels to students, ${ }^{172}$ and legal challenges have successfully restricted child pornography ${ }^{173}$ and exclusions from educational opportunities. ${ }^{174}$ Interpretive work, examining relationships countenanced or ignored by law, can provide critical handles on the violence done to children. Public force assaulting private force is still force, but norms invoked publicly can expose both kinds of violence to scrutiny and debate.

The rights claims mounted in each context may themselves trigger violence. Certainly, public investigations, mandated procedures, and bans on commercial activity do limit individual freedoms, sometimes excessively, and sometimes wrongly. But the choice in each case is not between violence and no violence, but between private violence and public violence. Reworking a theme developed earlier in this essay, I suggest that rights rhetoric does not create conflict, but rather accompanies the public violence used to challenge private violence. In this way, law may shift the balance of power in an already violent situation. By summoning the possibility of communal commitments in the face of genuine community divisions, rights claims also introduce something beyond violence. By speaking of all these things, we expose both legal violence and extra-legal violence for what they are, and by speaking, we enlarge a human capacity to be what we could be. ${ }^{175}$ Language "exists only within a 'differential' world, a world of conflicts and oppositions."176 Language not only can express and confirm power but also can challenge and claim it. ${ }^{177}$

guage they use. See, e.g., Radin, Market Inalienability, 100 HARv. L. REv. (forthcoming) (1987); see also L. Wirtsgenstein, Blue AND Brown Books 25-27 (1958) (describing difficulties with viewing language as involving application of rules).

171. See supra note 161 .

172. See Mills v. Board of Educ., 348 F. Supp. 866 (D.D.C. 1972); Pennsylvania Ass'n for Retarded Children v. Pennsylvania, 343 F. Supp. 279 (E.D. Pa. 1972); Education of the Handicapped Act, 20 U.S.C. $\S \S 1400-1461$ (1982); see also Hobson v. Hansen, 269 F. Supp. 401 (D.D.C. 1967).

173. New York v. Ferber, 458 U.S. 747, 758 (1982).

174. See Bob Jones Univ. v. United States, 461 U.S. 574 (1983) (refusing tax subsidy for university practicing racial discrimination); Brown v. Board of Educ., 347 U.S. 483 (1954).

175. See H. ARENDT, The Human CondrTion 175-81 (1958) (speaking makes us more human).

176. R. Terdiman, Discourse/Counter-Discourse: The Theory and Practice of Symbolic Resistance in Nineteenth-Century France 15 (1985).

177. The significance to oppressed groups of reclaiming language is a topic of wide discussion. See, e.g., B. Hooks, Feminist Theory: From Margin to Center (1984); The (M)other Tongue: Essays in Feminist Psychonnalytic Interpretation (S. Garner, C. Kahane \& $M$. Sprengnether eds. 1985). A significant power of language is to name oneself and one's experience. $P$. Freire, PEdagogy of THE OPPRessed 11, 88, 119 (1970). "Human existence cannot be silent, nor can it be nourished by false words, but only by true words, with which men transform the world. To exist, humanly, is to name the world, to change it." Id. at 76. This insight has meant much to women 
In arguing that the power of language can be harnessed to challenge even the violence of official state power, I am encouraged by the example in Cover's Violence and the Word of the power of words to challenge indifference toward official violence. ${ }^{178}$ Cover's essay offers an avenue for exposing violence and developing more articulate understandings of it. Cover highlights the points of connection between judicial acts that create legal meaning, and judicial acts that set in motion instruments of official violence. Further exploration of these points of connection could melt the numbness induced when lawyers separate interpretation and implementation. The judge depends on the cooperation of the police, warden, and prison guard, even as they, in turn, depend on the judge for the legitimacy of the force they exercise. Legal scholars could detail these processes of interdependence, showing how individuals in the system each go home at night feeling relatively powerless, yet wield enormous power together. Words about the meanings of violence can sharpen angles of criticism, rouse vigilance, and support acts of witness that could better hold those in power to account.

Similarly, scholars could seek to hold authorities to account, and promote bases for resistance, by nurturing aspirations to develop normative commitments through official interpretive acts. Building the repository of rhetoric endorsed by state power can enlarge the resources available to challenge such power, even when that rhetoric is initially "bonded" to acts of domination and to the instruments implementing such power. ${ }^{179}$ Once constructed and officially embraced, normative language can become loosened from its past uses, and turned around to limit its authors, if only through their own shamed or courageous self-restraint. ${ }^{180}$ Dworkin seems to have this in mind when he describes how "interpretation is in part a matter of justice" because it subjects well-established practices to critical assessment in view of changed conditions. ${ }^{181}$

Gandhi, for example, appealed to the norms of conduct enunciated by

as well as to men. See Z. Hurston, Their Eyes Were Watching God (1937); Le Guin, She Unnames Them, The New YorkeR, Jan. 21, 1985, at 27 (Eve unnames all that Adam named, and liberates creatures). See generally J. NoOnan, Persons and Masks of THE Law, supra note 80, at 6-12 (1976) (consequences of naming and labeling in legal doctrine); Felstiner, Abel, \& Sarat, The Emergence and Transformation of Disputes: Naming, Blaming, Claiming . . ., 15 LAw \& Soc'Y REV. 631 (1980-1981) (relationship between words and power in construction of disputes).

178. It may be more than indifference that must be shaken. As Richard Sennett has noted, "What people are willing to believe is not simply a matter of the credibility or legitimacy of the ideas, rules, and persons offered them. It is also a matter of their own need to believe." R. SENNETT, AUTHORITY 25 (1980).

179. Violence and the Word, supra note 7, at 1617-18 ("legal interpretation is a form of bonded interpretation, bound at once to practical application (to the deeds it implies) and to the ecology of jurisdictional roles (the conditions of effective domination)").

180. E.P. ThompSon, supra note 103 , at 258-69.

181. See R. DWORKIN, supra note 22, at 204; see also M. WALZER, supra note 153 , at $38-48$ (interpretation as social criticism requiring membership). 
the British. This appeal alone could not constrain the British Empire, but it helped support arguments for British self-restraint. Martin Luther King could challenge racial segregation and white supremacy in buses, schools, and public spaces, by joining the National Association for the Advancement of Colored People in its efforts to invoke the power of the Constitution, the courts, and equal protection doctrine. ${ }^{182}$ The tradition represented by "equal protection" captured prior struggles to enlarge the groups welcomed and included by the society. Those words, laden with that history, remained open for investment with still more meanings of inclusion. Previously, the legal rhetoric intoned by the civil rights activists had been used to justify official power and even official violence and exclusion. ${ }^{183}$ Loosened from its origins, however, rights rhetoric can wave as a banner to lead assaults on official violence itself.

This tribute to rights rhetoric should not hide how official violence explained by judicial rhetoric does violence. But power, exercised in silence, is even less likely to know restraint; for silence, while sometimes eloquent, can seldom challenge power. Language, accompanying power, enables the powerless to challenge power. Without language, and especially without language recognized by the powerful, those who would challenge or resist power are quite disabled.

Perhaps knowing this, the powerful sometimes use power to destroy even the possibility of language. Violence and the Word draws on the compelling interpretations of the silence induced by pain and torture in Elaine Scarry's book, The Body in Pain. ${ }^{184}$ Scarry describes, with words, the pain that does "not simply resist language but actively destroys it, bringing about an immediate reversion to a state anterior to language, to the sounds and cries a human being makes before language is learned."185 But with her words about pain, Scarry breaks a silence and also shows how silence is often produced by pain. By giving speech where there has been silence, Scarry challenges the power that produces silence even about silence.

In Violence and the Word Cover uses Scarry's language to launch his own eloquent exploration of the field of pain and death where legal interpretation takes place. This is not an abandonment of interpretation as an enterprise or as a normative icon. Rather, he shows how the tools of lan-

182. See R. Kluger, Simple Justice (1976).

183. See Korematsu v. United States, 323 U.S. 214 (1944) (approving detention of Japanese residents and American citizens of Japanese descent).

184. Violence and the Word, supra note 7, at 1602-03 \& nn.3-6 (citing E. SCARRY, THE BODY IN PAIN 29, 56-58 (1985)). Scarry's book is self-consciously about "the way we make ourselves . . . available to one another through verbal and material artifacts" and "the making and unmaking of the world." E. ScARRY, supra, at 22, 23.

185. E. SCARRY, supra note 184 , at 4 . 
guage and human gropings for meaning can be used to grasp portions of the world usually beyond words. New kinds of violence committed by the state initially elude words, ${ }^{188}$ but new words about violence can disrupt complacent conversations. Tactics to resist official violence, then, include exposing in detail the disguises of power and the meanings of violence. ${ }^{\mathbf{1 8 7}}$ Law talk can be searing, and words may shake the world.

A related tactic is to elaborate the justifications that legal actors offer in order to give those meanings bite for future critical use. One way to do this is to speak of rights as interpretive terms in communal dialogue. Yet, in maintaining this, I engage the two parts of this Essay not just in conversation-in a cozy talk-but in an angry disagreement. Violence and the Word puts a fundamental challenge to the first section of this essay. If, as I believe, Cover is right, and the violence inflicted by the judge threatens to destroy normative ties between the judge and those before the court, what, if anything, can be salvaged of the conception of community forged through interpretive conversation in the language of rights? This question gains additional significance when viewed through a wider lens, focusing not just on the violence imposed by the judge, but also on the brutality between litigants. Litigants use judicial power to inflict injury on one another; the battle metaphor, despite Milner Ball's aspirations, ${ }^{188}$ is often quite apt for the experience of litigation. ${ }^{189}$ Parties invoke the power of the court to resolve disputes, much as children turn to their parents to settle their disagreements with siblings or friends. Legal language, as the interpretative turn suggests, translates but does not initiate conflict; yet the translation can add to, subtract from, and even transform the meaning arising from conflict. The conflicts predate the invocation of authority, but the invocation of authority transforms the conflict, and threatens a new source of coercion. ${ }^{100}$ Nonetheless, a kind of community may develop even in litigation: the community of the litigants before the law.

186. This may be because they are secret-secret bombings, unnamed secret weapons, secret nuclear arsenals-and perhaps because they are unfathomable.

187. Perhaps the point is that power, official or unofficial, can produce violence or meaning or both, and the creation of ideological meanings that disguise violence confuses the matter. See $P$. Ricoeur, Lectures on IDEOLOGY AND Utopia 12-15, 310-11 (G. Taylor ed. 1986) (discussing legitimation and social identity produced by ideology). The work of Michel Foucault is devoted to exposing patterns of power, disguised by entrenched social meanings. See, e.g., M. Foucault, DiscrPLINE AND PUNISH (1971) (interpreting specific historical practices of social control and punishment); M. Fovcault, Power/KNOWLEdge, supta note 170, at 78-108 (explaining his methods and goals); M. Foucault, The History of Sexuality (1978) (relating discussions of sex to social domination). This kind of interpretive work may assist resistance to official violence by exposing its subtle workings.

188. See M. BALL, supra note 21 , at $132-33$.

189. See S. MILleER, The GoOd MOTHER (1986) (novel detailing damage to mother and family relationships inflicted during child custody litigation).

190. The meaning of judicial violence, however, may well be different in important ways when one of the parties invoking judicial power is itself the state. Cover's Violence and the Word uses 


\section{G. Who Is Before the Law?}

Litigants, as well as judges, are engaged in rights rhetoric, and the normative dimension of this engagement warrants attention. One potential meaning of judicial violence is its threat of punishment should a party refuse to appear, argue, and submit to judgment. Coercion to participate is certainly coercion. Its presence may well distort communication that otherwise would occur. The alternative, however, may be silence, or continued conflict. Legal discourse does create a shared world within the courtroom. Legal discourse converts the physical, economic, or psychological conflict into verbal coinage with physical, economic, and psychological dimensions. The significance of rights as tools of communal discourse, still bonded to official violence, gains importance in this context.

What happens to litigants in court? The risk of judicial coercion remains present throughout their exchange. But it is an indirect kind of power, which the litigants themselves can wield. Litigants make claims on the judge's power and demand that the opposing side participate in the process.

Robert Cover's Violence and the Word primarily addresses the power triggered by judges and the inevitable tie between this power and any language of meaning the judge pronounces. Legal language used by parties and their attorneys may carry quite different significance in their lives. It may give voice to entitlements only dimly perceived before. It may help each litigant recognize that there is another side to the story. Perhaps the equality of legal discourse is effected less through equal participation in the creation of legal meaning than through the shared experience of the threat of judicial violence. Rather than comparing children in court to adults, we might consider how litigation reduces all parties to children, powerless but pleading before an imperfect authority. The risks posed by legal violence can force litigants to reach new insights about what has meaning for them, or what matters most. When King Solomon crudely brandished a sword, he invited, or induced, some change in the selfunderstandings of the two women in his court who fought over a child. Rather than watch Solomon divide the child in half, one woman gave up her claim to custody, and urged that his life be preserved; this change of heart led Solomon to declare this woman the "true mother." 191 Violence,

criminal law as the dominant focus, and therefore addresses those situations when the state's invocation of violence is most obvious and most severe.

191. Minow, The Judgment of Solomon and the Experience of Justice, in THE STRUcture or Procendure 447 (R. Cover \& O. Fiss eds. 1979). I wrote this essay for Bob Cover's seminar, "Myth, Law, and History." I could not have written the piece without Bob's gentle but insistent encouragement and belief that there was a paper there, amid my many retellings of the biblical story. The assignment was to concentrate on the meaningfulness of concrete paradigms, by studying a specific myth, elaborating layers of meaning in a specific event, or playing out a metaphoric elaboration of 
although not "justified" or "redeemed," created opportunities for normative growth, at least for the litigants. ${ }^{192}$

The experience of litigation may be too brutal and polarizing to serve the purpose of encourgaging particular parties to join together in exploring normative commitments through interpretation. Litigation may foreclose rather than enable conversation. We have no hint that the women facing Solomon learned to converse together as a result of their legal dispute. Rights rhetoric, and the exploration of normative commitments through conversation, could be more free of official violence for parties who stay away from court and turn instead to settlement, mediation, or planning long before litigation. ${ }^{193}$ The creation of meaning through discourse may take place more fruitfully further away from the centers of official power while still gaining from their shadows. ${ }^{194}$

Rights rhetoric also may help to constitute a kind of communal authority without need of official structures to command respect or occupy normative space. ${ }^{195}$ In whatever context, the language of rights and the normative community it signals may be critical in structuring a particular kind of conversation. Through rights discourse, that conversation has ground rules that alter the exchange-or the silence ${ }^{198}$ - that would have

concepts in normative space. The challenge of that assignment is perhaps a life's work.

192. We have no reason to believe that Solomon himself was challenged to grow through this experience; indeed, he may have grown more inured to the exercise of violence in the name of normative justification. Cf. B. Brecht, The Caucasian Chalk Circle (J. Stern and T. Stern trans. 1983) (judge learns nothing from experience of resolving child custody dispute by having litigants engage in tug of war over child and seems to enjoy infliction of abuse on litigants).

193. Whether mediation and other informal methods for dispute settlement provide contexts more likely to promote authentic and meaningful speech-or instead are likely to introduce new forms of coercion-is a subject of considerable debate. See, e.g., Crouch, Mediation and Divorce: The Dark Side Is Still Unexplored, 4 FAM. ADvoc. 27, 33 (1982) (mediation may produce exploitation of one party); McEwen \& Maiman, Small Claims Mediation in Maine: An Empirical Assessment, 33 ME. L. REv. 237, 254-60 (1981) (reporting evidence that parties express greater satisfaction and compliance with mediated settlements than with adjudicated judgments in small claims area); MenkelMeadow, Toward Another View of Legal Negotiation: The Structure of Problem-Solving, 31 UCLA L. REv. 754, 829-40 (1984) (discussing effects of inequalities of wealth, power, and strength of personality in negotiation); Smith, A Warmer Way of Disputing: Mediation and Conciliation, 26 AM. J. CoMP. L. (Supp.) 205 (1978) (mediation can produce constructive process of mutual growth).

194. See, e.g., Mnookin \& Kornhauser, Bargaining in the Shadow of the Law: The Case of Divorce, 88 YALE L.J. 950 (1979) (processes of divorce law create opportunities for private orderings).

195. See The Bonds of Constitutional Interpretation, supra note 7, at 823-25 (discussing United States v. Tiede, 86 F.R.D. 227 (U.S. Ct. for Berlin 1979), decided by Judge Herbert Stern as article II judge for United States Court for occupied Berlin); Folktales of Justice, supra note 25, at 191-97, 199-202 (exploring possibilities of tribunals without official authority to try United States for its role in Vietnam War and to resolve disputes over rabbinic line affecting future of Messiah).

196. See S. Griffin, Pornography and Silence: Gulture's Revenge Against Nature (1981); Soifer, Listening and the Voiceless, 4 Miss. C.L. REv. 319 (1984); see also Rich, Cartographies of Silence, in A. Rich, The Fact of a Door Frame: Poems Selected \& New 1950-1984, 232,233 (1984) ("Silence can be a plan /rigorously executed /the blueprint to a life /lt is a presence /it has a history a form /Do not confuse it /with any kind of absence"). 
otherwise taken place. ${ }^{197}$ Judicial power may distort conversations, but some conversations-both in and out of court-would never take place without its threat. ${ }^{198}$

It is easier to build normative commitments by practicing interpretation in private communities, distant from centers of state power and organized violence, rather than in courts. Indeed, this theme was powerfully elucidated by Cover in his 1983 Supreme Court Foreword, Nomos and Narrative. ${ }^{199}$ Dethroning the usually privileged official norms generated by acts of state interpretation, that article celebrates the generation of norms by small integral communities that often act in resistance to the state and its organized power. For Cover, it was important to emphasize that the state may attempt to destroy local, private normative activities because they threaten to frustrate the state's thirst for a monopoly of meaning. ${ }^{200}$

This concern explains Bob Cover's frequent focus on questions of jurisdiction. This doctrine, invented by lawyers, organizes debate "over whether and when law might be used to limit the powerful."201 Jurisdiction is expressly about the relation between words and power. ${ }^{202}$

197. A similar point is made by those who worry about risks of shifting from formal adjudication of legal matters involving poor or relatively powerless people; here arises the risk that the kind of conversation that could have been instigated will not take place. See, e.g., Edley, Legal Reform and the Poor: Some Questions, Wash. Post, Jan. 16, 1984, at A11, col. 2:

No one has suggested that major antitrust suits or securities litigation be forced into binding arbitration. Yet there is some danger that reformers will rush to push poor people out of the traditional court system into uncertain, jury-rigged substitutes. . . The disadvantages that flow from having less income, sophistication and patience will still be real, even though the game has changed from litigation to Let's Make A Deal. And if "informal" means that rules and statutes can be bent in order to do what's "fair" in the specific dispute, what becomes of whatever protections the less powerful party might have had from the rigid laws and procedures?

198. In this country, legal discourse and judicial hearings may frame rituals when no other kinds of communication are possible. Through ritual, communities express what goes to the essence of their being. It is surely for such a reason that William Stafford named his poem, "A Ritual to Read to Each Other":

If you don't know the kind of person I am /and I don't know the kind of person you are /a pattern that others made may prevail in the world /and following the wrong god home we may miss our star. . . . And as elephants parade holding each elephant's tail, /but if one wanders the circus won't find the park, /I call it cruel and maybe the root of all cruelty / to know what occurs but not recognize the fact.

W. Stafford, A Ritual To Read to Each Other, in Stories that Could Be True 52 (1977).

199. Nomos and Narrative, supra note 23, at 4.

200. Compare Nomos and Narrative, supra note 23, at 11-19 (discussing "jurisgenerative" capacity of communities) with id. at 40-44 (describing "jurispathic" character of courts). Local communities may themselves commit violence, veiled or unveiled by interpretive acts. The racial discrimination of Bob Jones University, described in Nomos, is itself a kind of violence. See also W. SoyinkA, DEATH AND THE King's HoRseman (1975) (portraying British attempt to prevent local ritual in which horseman follows deceased king into world of ancestors).

201. Soifer, supra note 148 , at 912 .

202. See J. Vining, Legal Identity (1978). Vining begins with this meditation:

Jurisdiction is power. . . . With power a human being becomes a person. . . .

Since the abandonment of absolutism no human being is all powerful, even in concept. He has particular powers, and as these are defined he emerges as a particular person. The ques- 
Can words speak to power? How may normative language, which makes the violence of the official order more palatable, ever constrain that violence? Language is a thin shield and a fragile sword against actual violence. Even if uncorrupted by its association with power and force, ${ }^{203}$ the normative language of rights discourse may simply fail to express the desires and hopes of those who seek to curtail official violence. Legal language is often inflexible and unwieldy, abstract and formal. Sometimes people who win with legal language must face consequences they did not, and would not, choose. ${ }^{204}$ The cumulative effect of legal discourse also may be undesirable. Grant Gilmore warned that the pathway to hell is paved with due process. ${ }^{208}$

Moreover, legal language can never express individual experience. Its very claim to communal meanings, its dependence directly and indirectly on official sanctions, and its accreted past preclude that possibility. ${ }^{206} \mathrm{I}$

tion What is a judge? can thus be replaced by the question When does a human being appointed judge have power?

Id. at 13-14. Vining turns to an imagined situation where the Secretary of the Interior is attending a dinner party, and another guest orders him to suspend his decision to permit offshore oil drilling. What difference does it make if this guest is a judge, and what devices determine the power of the judge? Vining notes:

The secretary can appeal to others' sense of what a judge is and argue that the individual with the commission, in his black robes and in his special room, was still not acting in the role of the judge. . . .

If an individual who is not a judge wishes to challenge an act of the secretary's and persuade a judge to issue an order to the secretary, he must bring the judge to see that a judge can intervene in the situation. The secretary in turn will seek to show the judge that he cannot. Id.

This is the jurisdictional argument that occurs in every case.

203. And this is a big "if." See, e.g., M. Polanyi, Personal Knowledge 226-27 (1958):

We have seen that even though public power were originally based on terror, it could not fail to supplement its coercive force by persuasion, and that the thoughts cultivated for the purpose of controlling their people would inevitably gain ascendancy also to some degree over the rulers' own behaviour. . . .

[But] every new moral issue has evoked a clash of interests; how often moral progress had to be forced upon the privileged by the pressure of the oppressed; how the existing distribution of privilege has always granted its beneficiaries considerable powers to resist reforms that curtail their advantage, and how they have perpetuated injustice by force. . . W We may still doubt, therefore, whether the rulers of any society, however freely self-governed, will ever observe the claims of morality beyond what is needed in order to delude their subjects (and their allies abroad) to trust their professions of morality.

204. Bumiller, Victims in the Shadow of the Law: A Critique of the Model of Legal Protection,

SIGNS 421 (Spring 1987) (effects on discrimination victims of pursuing rights enforcement).

205. G. Gilmore, The Ages of American Law 111 (1977) ("In hell there will be nothing but law, and due process will be meticulously observed.").

206. The particular shape of legal rhetoric may be inhospitable to certain meanings, while welcoming to others.

Rights language offers a rich vernacular for the claims an individual may make on or against the collectivity, but it is relatively impoverished as a means of expressing individuals' needs for the collectivity. ... .

It is because money cannot buy the human gestures which confer respect, nor rights guarantee them as entitlements, that any decent society requires a public discourse about the needs of the human person.

M. Ignatieff, The NeEds of Strangers 13 (1984). 
have criticized rights rhetoric for its impoverished view of human relationships and its repeated assignment of labels that hide the power of those doing the assigning. ${ }^{207}$ And I find something terribly lacking in rights for children that speak only of autonomy rather than need, especially the central need for relationships with adults who are themselves enabled to create settings where children can thrive. ${ }^{208}$

As Cover reminded us, even the communal dimensions of rights claims are connected to violence. The assertion of community may be false, or may create a new line of exclusion enforceable by police power. Rights rhetoric can, and should, be exposed for its tendency to hide the exercise of state authority, even when exercised in the name of private freedoms. Rights discourse, like any language, may mislead, seduce, falsely console or wrongly inflame.

Nonetheless, I worry about criticizing rights and legal language just when they have become available to people who had previously lacked access to them. I worry about those who have, telling those who do not, "you do not need it, you should not want it." But, rather than trash rights, I join in the efforts to reclaim and reinvent them. Whether and how to use words to constrain power are questions that should be answered by those who lack it. For this task, rights rhetoric is remarkably well-suited. It enables a devastating, if rhetorical, exposure of and challenge to hierarchies of power. In Patricia Williams' words, people using the language of rights "imply a respect which places one in the referential range of self and others, which elevates one's status from human body to social being."209 The ambiguity and mutability of the words allow those who use them to shape and reinvent their meanings. ${ }^{210}$

Elizabeth Schneider has articulated how lawyers and parties, drawing upon their own experiences, can struggle to bring new meaning to legal rules, and how they can appeal to legal officials to give force to those meanings. ${ }^{211}$ Legal vocabulary, including rights, can be invested with meanings that challenge power and violence. Legal language, limited and partial as it is, can become a powerful medium for struggle. Each historic struggle has helped to transform inherited meanings. ${ }^{\mathbf{2 1 2}}$ For the speaker,

207. Minow, When Difference Has Its Home, supra note 15, at 127-30, 168-89.

208. Minow, Rights for the Next Generation, supra note 30, at 23.

209. Williams, supra note 59, at 416; see also Note, Petitioning and the Empowerment Theory of Practice, 96 YALE L.J. 569 (1987) (exploring how right to petition government for redress of grievances can empower individuals and groups).

210. Much of the first part of this essay is an effort to recover the relational aspect of a rights discourse that has so often emphasized autonomous individualism.

211. Schneider, supra note 85 , at 604-10 (discussing feminist lawyer's effort to shape new politi$\mathrm{cal}$ and legal meanings from her experience).

212. See generally Symposium: Sounds of Silence, 22 HARv. C.R.-C.L. L. REv. (forthcoming 1987). 
an inherited language is less a collection of pre-ordained meanings than "a means of transgressing factual constellations in the direction of an uncharted future." ${ }^{213}$ As a bridge between the world-that-is and alternative worlds-that-might-be, legal norms cannot belong exclusively to any state or set of officials. Those without official roles are as important to bridge present and future. Everyone can demand justification for every act of violence, committed against the state, or away from the state, or in the name of the state. ${ }^{214}$

\section{After the LAw: INTERPRETING RightS}

And so I appeal to a voice, to something shadowy, I a remote important region in all who talk: / though we could fool each other, we should consider-/lest the parade of our mutual life get lost in the dark.

\section{-William Stafford ${ }^{215}$}

I have the luxury, as a scholar, to criticize. I can step back and criticize basic tools of legal practice, like rights, for preserving assumptions about human autonomy that I believe are contrary to social experience and likely to limit social change. Yet when I write a brief, supervise students in their clinical work, or talk to professionals in the trenches, I wonder sometimes whom I am helping and whom I am hurting by criticizing rights. It turns out to be helpful, useful, and maybe even essential, to be able to couch a request as a claim of right. By "helpful, useful, and maybe even essential," I mean not just in terms of winning a given case or convincing a particular official to do a good thing, but in helping to constitute the kind of world where struggles for change can in fact bring about change, and where struggles for meaning and communality can nurture both.

Rights can be understood as a kind of communal discourse that reconfirms the difficult commitment to live together even while engaging in conflicts and struggles. The struggle to make meaning of human existence may well demand our separation into groups away from, even antagonistic to, the larger community. If this is the case, then the discourse of rights may be all the more important as a medium for speaking across conflicting affiliations, about the separations and connections among individuals, groups, and the state. The very act of summoning "community," through

213. F. Dallmayr, supra note 106, at 97 (discussing J.P. SARTRE, Being and Nothingness (1956)).

214. Folktales of Justice, supra note 25 , at 181-82.

215. W. STAFFORD, supra note 199 , at 52. 
a language of rights, may expose the divisions within the community-and even beyond it.

Legal interpretation, at such moments, happens not just in official acts by official actors. Legal interpretation also occurs through resistance, compliance, and investment of old forms with new meanings. Legal interpretation happens when non-officials seek to hold officials to account, either in terms the officials themselves have offered as rationales or in new terms, embodying normative commitments that have not before made their way into the official canon of meaning. Legal language is never transparent to experience; it constrains and limits what individuals mean even as it conveys a communal meaning. And the communal meaning may well occlude the conflict it resists. Legal meanings pronounced by officials cannot be severed from the violence and power they seek to rationalize; nor can they be reduced to those acts of violence and power. Because private violence can be as bad as official violence, both public and private efforts to craft legal meanings and normative commitments are important for struggling against oppression.

What happens after the law, after official legal pronouncements, good or bad? The interpretive framework suggests that legal pronouncements are possessions of the dispossessed. ${ }^{216} \mathrm{We}$ can listen to rights as a language that contains meaning but does not engender it, as sounds that demonstrate our sociability even while exposing the uniqueness of the speaker. Legal language, like a song, can be hummed by someone who did not write it and chanted by those for whom it was not intended. ${ }^{217}$

Language is nuanced enough to express, "No, that's not what I meant," or even, "There are no words to say what I mean." The language of rights is, or could be, nuanced enough to express, "I am connected to you in my very willingness to observe your boundaries," or "I do not belong to

216. Appleby, The American Heritage: The Heirs and the Disinherited, 73 J. AM. Hist. (forthcoming 1987) (noting how others describe constitutional interpretation as battle among heirs to founding fathers, and offering instead conception of battle among disinherited).

217. Hanna Pitkin has suggested that a tension between ideals and institutional practices may actually create the opportunity for a critical leverage on each: She writes:

The tension may arise through either of two possible historical sequences. Perhaps men conceive some ideal or goal or purpose, and develop an institution or a set of procedures for achieving and perpetuating that goal through time and in the activities of many men. They draw up a set of laws, or institute a school, or create a new agency. But rules require interpretation, and institutions have a way of developing purposes and directions of their own. After a time, men may find themselves torn between their commitment to the original purpose, and their commitment to the institutions that were supposed to bring it about. Or, conversely, a society may gradually and without any deliberate intent develop certain institutionalized or ritual ways of proceeding, and from these it may eventually abstract rules or principles or ideals. At first these rules or ideals may be merely descriptive abstractions of how the institution works, but after a time they become critical standards in accord with which the institution can be evaluated and reformed. Again the result is a tension between the "ideal substance" and the "practical form" in which it is embodied.

H. Pitkin, Wittgenstein and Justice 187 (1972). 
your community, with your norms, but I lay claim to some shared terms in demanding that you respect my separateness."218 Perhaps people can work through legal interpretation to communicate disjunction, misunderstanding, even the right to avoid conversation. After the law, we have each other, and the steady burden of learning to live together and apart.

In a seminar entitled "Myth, Law, and History," in the fall of 1977, Robert Cover introduced Yale law students to myths and histories about the creation of law and about central legal preoccupations, such as guilt and innocence. The theme of creation launched a journey through biblical and Talmudic texts, through American constitutional history, and through studies of the law-giver, Moses. ${ }^{219}$

Then, the discussion turned to the Oresteia. Here was a world of divine chaos. Blood-feuds, once started, have no end. Human beings are the hapless victims of the gods' intervention. Aeschylus transforms a well-known story into a sharp dilemma about the relations between justice and violence, and between conflicting normative commitments.

The House of Pelops is cursed. Conspirators murder Agamemnon upon his return from the Trojan Wars. Apollo commands Orestes to avenge his

218. See Levinson, Professing Law: Commitment of Faith or Detached Analysis?, 31 Sr. Louis U.L.J. 3 (1986) (discussing loyalty oaths). Elsewhere, I have written about this power in poetry:

Feelings of powerlessness may at times preclude speech, even speech about powerlessness. In this context, I am reminded of a poem so expressive of the difficulties in finding words that it conveys silence even as it speaks.

The poet W. S. Merwin wrote this short, abrupt verse, entitled: "Elegy":

Who would I show it to

Ending with a preposition, in mid-thought; ending without punctuation, and relying on reference without definition; stand-in words like "who," "I," and "it" for undisclosed references: the poem is perplexing. Incompletion and dependence on what remains forever unsaid weigh heavily in the poem, and at least in some measure, may be its message. Yet, probing for some more specific meaning, the reader could try to relate to the text and draw from the reader's own experience. "Why such incompletion?" the reader can ask. What could be the "it" in the poem-perhaps the elegy in the title. The "I"-perhaps the poet. The "who"-perhaps no one known, no one alive. Perhaps the poem means the poet's relationship with someone has been so interrupted, so cutoff, perhaps by death, that the very idea of memorializing the lost one seems futile. The one person who could understand and appreciate the poet's efforts to write an elegy is gone. The possibility of mourning that could reach closure is so dim that the poet cannot even complete the thought about how to try.

And yet, if any of this discussion echoes the meanings the author intended or meanings sensed by readers other than me, another twist in the meaning remains. If I am able to grasp some portion of the poet's thought and feeling, some sense of how great would be the poet's grief, loss, and interruption that produces such a statement of the impossibility of statement, then indeed the poet has communicated. And the silence, between strangers, between author and reader, has indeed been broken. Conversation where there has been silence may best begin this way, in expressions of what has been and perhaps remains inexpressible.

Minow, Many Silent Worlds, 9 W. New ENG. L. Rev. 197, 204-05 (1987) (footnotes omitted).

219. The readings brought together three works about Moses, each by a German writing in the 1930's. See M. Buber, Moses (1946); S. Freud, Moses and Monotheism (1939); T. ManN, The Tables of the Law, in 2 STORIES OF A LIFETIME 288 (1961). 
father, Agamemnon, by murdering his mother, who herself had planned Agamemnon's death. Pursued by the Furies for the act of matricide, Orestes is inextricably caught between clashing moral imperatives. Apollo directs Orestes to appeal to Athena, because she combines male and female virtues, and embodies the virtues of moderation, restraint, and persuasion. Yet, as Athena knows, the gods are divided, so there can be no direct appeal to their authority. She chooses ten mortal men of Athens to act as a jury of peers. ${ }^{220}$ The gods, though, will make the jury's judgment supreme. When the jury casts its lots, they come out evenly, and Athena casts the deciding vote. She pardons Orestes, but her decision topples the prevailing divine legal order. Mercy does violence to law. Athena has challenged the power of the Furies by excusing Orestes from their charges; she has dislodged the divine order by appointing a jury of mortals. Responding to the angered Furies, Athena interprets the jury vote: You have not lost, she says, for the vote was even. Athena proposes that the Furies, the Olympian gods, and men will share control of the legal order, and indeed, share sovereignty in the minds of humanity. With a new role-to punish those who offend the due processes of law-the Furies are transformed, and become the Eumenides, the "Kindly Ones." Sky and earth, eagle and snake, freedom and necessity, the new order and the old-all are joined in a new iteration of the continual struggle.

There was a moment in the class when Bob Cover conjured up the closing choice reached by the gods to create a public sphere, beyond the conflicts of blood feuds. It was a choice to turn the instruments of justice over to humans beings. It was a moment of hope and a moment of necessity. We gained the right to interpret our own meanings, and pursue our own justice, though we remain tragically caught in ignorance and violence as we compete for the power to give reality to our visions.

[A]s long as legal interpretation is constitutive of violent behavior as well as meaning, as long as people are committed to using or resisting the social organizations of violence in making their interpretations real, there will always be a tragic limit to the common meaning that can be achieved. ${ }^{221}$

220. Athena charges the human jury to retain a sense of fear even while engaging in selfgovernance:

No anarchy, no rule of a single master. Thus/I advise my citizens to govern and to grace,/and not to cast fear utterly from your city. What/man who fears nothing at all is ever righteous? Such/be your just terrors, and you may deserve and have/salvation for your citadel, your land's defence,/such as is nowhere else found among men, neither/among the Scythians, nor the land that Pelops held.

Aeschylus, Eumenides 160 (R. Lattimore trans. 1953) (lines 698-705).

221. Violence and the Word, supra note 7, at 1629. 
Interpreting Rights

May we learn to interpret our suffering; may we recover our rights to make meaning. 